\title{
Accounting, Ideological and Political Work and Chinese Multinational Operations: A Neo-Gramscian Perspective
}

\begin{abstract}
This paper critically analyses the role of accounting in China's new phase of politically driven economic reforms, which is the international expansion of Chinese enterprises. In particular, the paper examines how China's multinational state-owned enterprise (SOE) and its managers conceive of, and use, accounting and control practices in response to the state's international political and economic objectives. Drawing upon neo-Gramscian concepts of hegemony, this study contends that the Chinese Communist Party (CCP) has sought to create and maintain its hegemony by turning its political ideologies into initiatives of "economic development", articulated through intensive ideological and political work exercised from the national to the organisational level. The study highlights the role of SOE managers in accommodating accounting and control practices in line with the state's hegemonic and ideological demands. Crucially, it reveals the ability of managers to coordinate and balance the state's political ends and the enterprise's economic interests, where there is a selective use of accounting and control practices deployed for reasons beyond their economic functionality. This paper argues that it is necessary to include the superstructure and economic base of the Chinese state in a hegemonic analysis, and to investigate how the managerial cadre engages with ideology building at the organisational level. By focusing on the Chinese state's new political dynamism regarding the expansion of multinational business operations, this paper provides new insights into the complexity of the motivations underlying the use of accounting and control practices in a globalised context.
\end{abstract}

Keywords: Accounting and Control Practices; Ideological and Political Work; Chinese Multinationals; Hegemony; Ideology 


\section{Introduction}

There has been significant research interest in emerging and less-developed countries (Hopper, Tsamenyi, Uddin \& Wickramasinghe, 2009; Alawattage, Hopper \& Wickramasinghe, 2007; Alawattage \& Wickramasinghe, 2009), particularly in terms of how intrinsically 'Anglo-American' practices of accounting and control interplay with local contexts underpinned by distinctive social, political and cultural factors (Alawattage, Wickramasinghe \& Uddin, 2017; van Helden \& Uddin, 2016). In this respect, China has so far offered a fruitful context, mainly because of what appears to be an 'established' socialist regime, with distinctive and immutable cultural facets (Chow, Lindquist \& Wu, 2001; Tsui, 2001; Douglas \& Wier, 2005; Du, Tang \& Young, 2012).

What has recently become of more interest, however, is the path of the ongoing political and economic reforms adopted by the Chinese institutions and their political elite. The latter appear to follow an arguably unique approach to economic development and societal transformation, including the evolutionary and selective absorption of capitalist ideas during the process (Chow, Duh \& Xiao, 2007; Xu, 2011; Yang \& Modell, 2015), whilst simultaneously maintaining and reinforcing political control and thus the legitimacy of the one-party system (Chinese Communist Party, CCP). It is the interplay of these different economic reforms over time, the recent and active pursuance of a political hegemony beyond its national borders, and how this is translated at the organisational and managerial level (specifically in terms of accounting and control practices) that has caught our attention.

A strong indication of China's engagement with a new hegemonic order has been the rise of international operations by Chinese state-owned entities and other Chinese multinational corporations (MNCs). Recent studies in international business and management, policy research and human resource management have revealed relatively unique forms and discourses of management, strategy and policies adopted by managers in Chinese MNCs (Kernen \& Lam, 2014; Cooke, 2014; Quer, Claver \& Rienda, 2012; Cui \& Jiang, 2012). The Chinese model of MNC development has arguably become an imperative, as reflected by its increasing outward foreign direct investment (OFDI) ${ }^{1}$ policies, which have led to a dramatic growth in Chinese MNCs. This is particularly manifested in Africa (and admittedly more globally now), as illustrated by the achievement of 'near monopoly' positions in the telecommunication, mining and construction industries of many African countries (Grimm, 2014; Wang \& Elliot, 2014). These events reflect the intent of China's latest economic reforms, underpinned by a politically-led OFDI strategy and a re-orientation of government policies with regards to state-owned enterprises (SOE) (Grimm, 2014; Wang \& Elliot, 2014; Huang, 2011). This prompts us to explore the recent patterns of accounting and control practices in this new phase of economic reform (namely the expansion of the

\footnotetext{
1 Statistics shows China's OFDI had reached over 140 billion US dollars in 188 countries in 2018, which makes China the second biggest foreign investor in the world. Sourced from the '2018 Statistical Bulleting of China's Outward Foreign Direct Investment', jointly published by the Ministry of Commerce of the PRC, National Bureau of Statistics of the PRC and State Administration of Foreign Exchange.
} 
multinational and international operations of SOEs), leading to the following research question:

How do SOE managers conceive of, and use, accounting and control practices in the multinational operations of SOEs, in pursuance of the political and economic objectives of the state and of the Chinese Community Party (CCP)?

To this end, we analyse the trajectory of a construction SOE company's overseas expansion from the start of the Chinese economic reforms to the present, and to theorise the role, design and use of accounting and control practices in its overseas operations during the most recent period of economic development. Our empirical material is drawn from documentary evidence, interviews and field visits to a Chinese state-owned multinational construction enterprise, referred to anonymously in this paper as 'International GS'. The case design was firstly inspired by recent studies in the Chinese public sector concerned with the evolutionary nature of China's reform policies while being mindful of agential power, interests and practices at the micro level (Chiwamit, Modell \& Yang, 2014; Yang \& Modell, 2013, Zan \& Xue, 2011). Although these studies exposed the retention, and reinforcing, of the state hegemony during the previous periods of economic transition, the co-existence of marketoriented practices (and the underlying capitalist ideology) and those of the Communist-era, our study analyses accounting and control practices as the instruments of the prevailing political hegemony of international expansion and the managers' own engagement with such practices.

In terms of the study's theoretical standpoint, we rely on neo-Gramscian conceptualisations of hegemony (Laclau \& Mouffe, 2014; Cox, 1981) and initially draw upon prior work on the political and ideological role of accounting (e.g. Cooper, 1995; Goddard, 2002, 2005; Alawattage \& Wickramasinghe, 2008; Spence, 2009; Yee, 2009; Ashraf \& Uddin, 2015). Gramsci's original idea of a hegemony relates to the way in which the status quo (and the position of the ruling class) is maintained in the presence of larger groups with different economic and political interests (Cooper, 1995). A hegemonic order is primarily constructed through the diffusion of an ideology that is reflected or embodied in social practices, organisations and institutions, thereby providing a 'set of guiding principles' for individuals to voluntarily adhere to whilst maintaining the state's dominance and status quo. From this vantage point, accounting is not in itself an ideology (Cooper, 1995) but nonetheless serves the interests of the powerful by virtue of its ability to be 'naturally' positioned as a 'neutral' provider of facts. This characterisation of accounting practices and discourses enables a particular ideology and hegemony to prevail and prevents other avenues from being considered.

However, and proceeding beyond the discursive and largely consensus-building features of accounting that are typically analysed at the superstructural level, we argue that a practical and managerial engagement with particular accounting and control practices at the economic base can also arise as part of the prevailing political ideology. It is in this light that we mobilise the neo-Gramscian concept of articulation (Laclau \& Mouffe, 2014) to investigate the materialisation of ideology at the organisational level (notably practices known as ideology and political work), and how it informs the use of accounting and control practices. Lastly, and in view of China's increased involvement in international political and economic arenas, and the central role played by multinational SOEs, we also draw on Cox's (1981) notions of hegemony in 
international relations to frame the role played by Chinese multinational SOE managers (and their accounting and control practices) in the externalisation of China's hegemonic order and the normalisation of its politico-economic discourse at the global level.

We seek to contribute to the literature by highlighting how the use of accounting and control practices interplay with Chinese ideology and political work in an international setting. Similar to Alawattage and Wickramasinghe (2008), we first document the coexistence of a number of traditional and so-called 'modern' (Western-inspired) accounting and control practices, which are operational mainly in terms of producing and communicating information to managers. In particular, we note the design and use of a 'Western-inspired' project budgeting and target costing system in the case study organisation as buttressed by construction-related and traditional practices known as Cheng Jian Zhi (military management) and engineering norms. Secondly, SOE managers appear to selectively ignore or downplay the rational (technical) implications of these accounting and control practices. Instead, they seek to ensure that these practices operate in subordination to the hegemonic imperative of ensuring China's international leadership and standing.

Our attention to accounting and control practices is admittedly purposeful since they are one of the most studied themes in the 'China and accounting' literature (Tsui, 2001; O'Connor, Chow \& Wu, 2004; Wu, Boateng \& Drury, 2007; Duh, Xiao \& Chow 2009). Underpinning the evolution of accounting and control practices is not only a response to the political mandate of adopting 'innovative' managerial practices as part of wideranging reforms (Lin \& Yu, 2002), but also as an ongoing interaction with the remnants of prior economic reforms and those from the Communist-era planned economic system.

The remainder of the paper starts by briefly reviewing the prior work on accounting and control practices in China. Gramsci's (1971) tenets, insofar as they relate to the study of accounting and the role of the state are reviewed, followed by neo-Gramscian conceptions (Laclau \& Mouffe, 2014; Cox, 1981). This is followed by a description of the methods, setting and design of the case study, inclusive of the challenges in engaging in such analysis. We then provide an overview of China's economic reforms with an emphasis on the construction industry and the design and use of accounting and control practices in the case study company's current multinational operation in light of our theoretical framework. We conclude the paper by summarising our main findings and contributions and offering implications for future research.

\section{Literature review}

\section{Prior research on accounting and control practices in China}

The effects of economic reforms on accounting and control practices is a theme that has often been addressed in Chinese-based research (e.g. Bromwich \& Wang, 1991; Firth, 1996; Chow et al., 2007), and as a result, the research focus has changed in response to the evolutionary nature of China's economic development and policies. Studies set in the earlier stage of China's economic 'journey' mainly focused on examining the adoption and diffusion of western management accounting and/or control mechanisms in Chinese enterprises (Scapens \& Yan, 1993; Yan \& Gray, 1994). 
In the main, these studies argued that the introduction of market-oriented policies and economic entities such as international joint ventures improved knowledge transfer and competition, which in turn provided opportunities for localising western-based 'modern' accounting and control systems in China (Bromwich \& Wang, 1991; Yan \& Gray, 1994; Firth, 1996; Chalos \& O'Connor, 2004, Chow et al., 2007). These findings were usually compared to practices in state-owned entities, and authors often highlighted crucial issues associated with government intervention, state ownership and restrictions on managerial autonomy as an impediment to the diffusion and/or effectiveness of these market-based accounting and control practices in SOEs (Chalos, O'Connor \& Zijian, 1999; O'Connor et al., 2004; O'Connor, Deng \& Luo, 2006). A third stream of studies has been undertaken more recently and has drawn from more recent instances of economic reform (e.g. O'Connor, Vera-Muñoz \& Chan, 2011; Liu \& Pan, 2007; Xu \& Uddin, 2008; Fleming, Chow \& Chen, 2009; Tsamenyi, Sahadev \& Qiao, 2011). This work has emphasised the relevance of indigenous factors and local managerial notions and approaches in understanding the "Chinese framework of accounting system" (Scapens \& Yan, 1993). Particular attention has been paid to the impact of China's political economy on the development of accounting (Ezzamel \& Xiao, 2015; Zhang \& Andrew, 2016; Gong \& Cortese, 2017; Li \& Belal, 2018; Modell \& Yang, 2018). This has been, in effect, a departure from the prior investigation of 'mainstream techniques' and is instead a 're-investigation' of accounting and control practices in China with a view to challenging the perceived 'western predomination' associated with Chinese accounting research.

A concurrent development has been the improving fortunes and dynamism of Chinese SOEs and of the underlying state-driven interests in pursuing economic reforms (Du et al., 2012; Chow, 2011). In particular, there has been more attention paid to the political (and geopolitical) dimensions of China's economic reforms and the role played by accounting and accountants (Xu, Cortese \& Zhang, 2013; Yee, 2012). Yet very few empirical studies have analysed these practices from beyond the economic realm to reveal the role of China's social and political process (O'Connor et al., 2004, 2006; Hassard, Morris, Sheehan \& Yuxin, 2010; Yang \& Modell, 2015). The political implications have been downplayed, particularly in relation to the overlying of various historical junctures associated with China's economic progress (Duh et al., 2009; Wu \& Boateng, 2010). Instead, Chinese economic reforms have often been rigidly classified as independent historical events (e.g. emergence of joint ventures and stock markets, entry to the World Trade Organisation, and the privatisation of SOEs) and selectively examined in relation to emergent accounting innovations and practices. Consequently, such work appears to have sidestepped the point that economic reforms are an evolutionary process that are driven by, and adjusted to, the state's changing political strategies and needs over time (Yang \& Modell, 2015). The apparent co-existence of conflicting ideologies (underpinning various reforms) and intertwined interests of participants within these reforms have been captured in very few studies. Mindful of the continued dominance of the state in shaping the economic, political, cultural and social landscape in China, we depart from previous studies by mobilising the concept of hegemony to investigate the rationale and the means of the state in promoting economic reform, and the political implications of such reform on actors at the economic level (e.g. SOEs and their accounting and control practices). We elaborate on this point below. 


\section{Gramsci's notion of hegemony}

For Gramsci, hegemony is defined as a power relationship in which a ruling class, rather than principally relying on coercive enforcement, establishes and maintains its supremacy by securing consent from the subordinate classes (Bates, 1975). In this respect, Gramsci contends that ideology plays a central role in achieving consent, because it is formed as a mental framework consisting of a particular set of ideas, dominating social thinking in a society, and influencing how individuals construct their subjectivity in social relations (Hall, 1986; Yee, 2009). The construction of a hegemony is therefore determined by the diffusion of an ideology which guides individuals to voluntarily coalesce around a 'collective will' that would be in line with hegemonic class dominance and leadership (Goddard, 2002; Yee, 2009). This conceptualisation further implies that ideology is a purposefully tailored creation through which to achieve a political end (Cooper, 1995; Goddard, 2002; Ezzamel et al., 2007). The political nature of ideology is echoed in Gramsci's own view that rather than being free- floating ideas, ideology has a material existence which prevails in social practices and is embodied in the institutions and organisations within which these social practices take place (Simon, 1982; Goddard, 2002). This perspective underpinned several hegemonic accounting studies which emphasised how a performative ideology becomes materialised and entrenched in the accounting domain in the form of accounting discourses, regulation making and professionalisation (Richardson, 1989; Goddard, 2002, 2005; Ezzamel et al., 2007; Yee, 2012). ${ }^{2}$ Those studies revealed accounting as an 'ideological weapon' (Goddard, 2002), whereby an accounting system can be purposefully organised as a malleable object in order to reflect and enable different political ideologies as part of their hegemonic processes (Ezzamel et al., 2007). ${ }^{3}$

Many China-based studies adopted this ideological perspective by explaining how the accounting profession responded to the state's hegemonic demands during China's political and economic transformations (Ezzamel et al., 2007; Yee, 2009, 2012; Xu, Cortese \& Zhang, 2013, 2014, 2017). Central to their explanation is to envisage the state as the key strategic terrain in the process of designing, maintaining and diffusing ideologies. These authors found that the CCP, as the dominant power in China, strategically worked on ideological aspects to obtain consent for its political and economic initiatives, which in turn reinforced and maintained the legitimacy of its regime of control (Yee, 2009, 2012; Xu et al., 2013, 2014, 2017). Accounting, in their view, represents the functional and material aspects of this ideology, as it is used as a tool to promote and naturalise the CCP's political ideology of "economic development", and potentially to denigrate, exclude and obscure alternative ideas and concepts (Ezzamel et al., 2007). This ideology of "economic development" has been acknowledged in recent studies in political science, which claimed that China, as a

\footnotetext{
2 Cooper (1995) concurred that ideology is "...seen as working through accounting to give certain signifiers an authoritative position in terms of their role of helping us to understand the world, and at the same time, to silently exclude other ways of understanding the world." (1995, p. 176).

3 For instance, accounting concepts such as 'value for money' and 'efficiency savings' became natural ideas (Cooper, 1995) that were crucial to Thatcher's ideology of 'small government'; with relatively little opportunity for alternative ideas or solutions to emerge.
} 
single-party state, has been building an alternative hegemonic regime by placing "economic development" as the central and dominant ideology to ensure China's political hegemony (Su, 2011; Rucki, 2011; Lieber, 2013; Xing \& Shaw, 2013). Drawing upon the role of the state and the CCP in the ongoing economic reforms, they argued that economic development has become embedded as 'common sense' in the consciousness of the masses and has determined the legitimacy and stability of the regime (Su, 2011; Xing \& Shaw, 2013).

Although this hegemonic explanation provides a new way of understanding the political motivations behind the development of accounting, alongside China's economic reforms (Yang \& Modell, 2015), a relatively unique aspect of the Chinese context is the interdependence between the success of the state's political hegemony work and its actions within the economic domain. For example, political appeals can be couched in a language of economic initiatives but at the same time, can be diluted by material conceptions of economic development (Lieber, 2013; Su, 2011). This type of 'practical' ideology building is effective in achieving consent because it ensures that the legitimacy of the hegemonic group's control is associated with the state's economic performance, whilst the latter is still seen as serving the major interests of the masses. The importance of the economic base in building this 'practical' ideology further suggests that economic organisations, such as SOEs, play a significant role in China's portrayal and enactment of its hegemony. In this way, our paper seeks to respond to calls by previous authors to examine more closely the role and dynamic nature of SOE management (and their accounting and control practices) in promoting China's ideology of "economic development" (Du et al., 2012; Chow, 2011).

Although we argue that a hegemonic analysis can contribute to a better understanding of how accounting and control practices are enacted in SOEs (particularly in the context of their international activities and investments), we also agree with previous authors in terms of the need to unravel the dichotomy of 'the superstructure and the economic base' in Gramsci's class-based hegemonic notions ${ }^{4}$. Originally developed to explain 'class antagonism' (between the bourgeoisie and the proletariat) within a capitalist society, Gramsci stated that it is impossible to impose the ideology of the dominant group over society as a whole. Instead, the dominant group needs to constantly make necessary compromises and trade-offs during a process of 'ideological formation' (Gramsci, 1971). A successful hegemonic ideology would bind different social elements into a 'historic bloc', through which the core interests of the dominant group can be accepted, maintained and naturalised as a necessity of the state and decisive for social unification, leading to structural reproduction (Yee, 2012; Joseph, 2000). This idea did offer valuable insights into how developments in the economic realm and the formation of accounting professions, regulations and discourses worked as a means of forming a historic bloc and materialising political ideologies in the accounting realm (Goddard, 2002; Ezzamel et al., 2007; Xu et al., 2014,

\footnotetext{
${ }^{4}$ Gramsci's notions of political society and civil society are usually recognised as the 'superstructural' constituents of the state representing different power relations in a hegemony. While political society is made up of the state's coercive organs (e.g. the police, the courts, the tax agencies) for legitimating and regulating political and economic systems, civil society consists of all other entities with the exception of those involved in the production process (the organisations operating within the so-called economic base).
} 
2017), however, the explanatory power of these studies has been limited to the construction of ideology at the superstructural level of the state ${ }^{5}$.

Instead, we argue that an analysis of state hegemony cannot be comprehensive if the economic base of the state is merely conceived as a passive receiver of values and ideas from the superstructures, and de facto excluded from a deeper appreciation of the aforementioned hegemonic dialogue (Cooper, 1995; Spence, 2009; Alawattage \& Wickramasinghe, 2008). The materialisation of ideology takes place at each level of a social structure and players within the economic realm, such as corporate managers and employees, are also a dynamic part of a hegemonic bloc. In their study of labour control and political hegemony set in Sri Lankan tea plantations, Alawattage and Wickramasinghe (2008) refer to the 'mundane of labour control and accounting' (p. 303-304) that are used to sustain the political hegemony rather that provide a basis for making cost-effective, efficient or profitable decisions. The authors explain how a number of communal controls, calculative practices and managerial rituals operate in these contexts primarily as instruments to reproduce, represent and validate the traditional 'plantation-economy' regime of labour control, and thus maintain the hegemony of global capital over labour. The records, reports, budgets and meetings associated with the production of accounting and control information thus become divorced from their technical 'core purposes' of managing costs/activities and underpinning rational accountability relationships (i.e. between owners/managers/employees), and instead mainly serve to 'illuminate' or underline existing feudal and paternalistic forms of control, and thus maintain a political hegemony.

The above is particularly important to a hegemonic analysis of accounting and control practices in China for two reasons. First, it asserts the role of accounting as a 'participating', and not neutral, tool of political hegemony at the economic level. As concluded by Alawattage and Wickramasinghe (2008, pp. 330-331), accounting and control practices are not merely rejected or resisted in politically charged organisational settings, and instead can serve to reproduce the status of a political hegemony. This requires an analysis beyond the boundaries of organisational settings, and in our case, emphasis being placed on the Chinese state's most recent variant of its hegemonic order. Secondly, the interdependence of, and interplay between, China's 'ideology and political work' and the economic dimensions are manifested within many Chinese companies. This applies especially to SOEs, given their affiliation with both political and economic realms and their strategic involvement in China's quest for reforms that are 'palatable' to the prevailing hegemonic order. This study thus seeks to address a relatively less discussed angle of analysis by exploring how a state's hegemonic order becomes embodied and enacted at the economic base, as well as the political and politicised role of accounting in a multinational SOE (Sassoon, 1980; Cooper, 1995; Alawattage \& Wickramasinghe, 2008). In order to facilitate this micro-

\footnotetext{
5 One of the key arguments is that accounting systems help the state to achieve hegemony because the accounting profession and community, as important constitutes of civil society, reflected and balanced both coercive and consensual approaches of the state in formulating and enforcing accounting regulations, standards and disclosure requirements (Richardson, 1989; Cooper, 1995; Goddard, 2002; Yee, 2009).
} 
perspective and emphasise organisational practices, we mobilise specific neoGramscian conceptions for our theoretically informed analysis.

\section{Neo-Gramscian perspectives}

In order to empower a hegemonic interpretation that can include the dynamism of players at the economic base, it becomes necessary to break away from class essentialism, ${ }^{6}$ which conceptualise the economic base of a society as the dominated class and as such, inherently rules it out of the process of ideological formation. This original conception of class has been criticised in neo-Gramscian work. For instance, Laclau and Mouffe (2014) argued that class is merely one of many collective identities that engage in hegemonic social changes. They argued that the logic of hegemony can be generalised at every level of society and of social groups, as long as specific relations can be established between social elements, with certain social meanings fixed to form collective identities that are in accordance with a hegemonic domain (Smith, 2012; Laclau \& Mouffe, 2014; Thomassen, 2016; Wojczewski, 2018). In other words, hegemony can be understood as a process of articulation - a struggle for the 'fixation' of particular meanings and identities in a specific domain, which in turn results in the establishment of a hegemonic discourse, such as political ideology. Hegemony can thus be seen as the "political articulation of different identities into a common project that becomes our social horizon" (Carpentier \& Cammaerts, 2006, p. 964). This concept of articulation underpins the openness of hegemony to social complexity and facilitates an investigation of the materialisation of an ideology at the industrial/corporate base, for example in terms of how this becomes infused with various organisational procedures, processes and practices.

Laclau and Mouffe's conception is also useful in understanding the processual nature of hegemony. It is generally agreed that a hegemony cannot be permanent since social relations within a hegemony tend to be unstable or fail to be reproduced overtime (Simon, 1982; Hall, 1984). To maintain and strengthen its hegemonic position, the ruling power needs to make constant efforts by (re)balancing political forces and interests, (re)shaping state institutions and systems, and (re)constructing hegemonic discourses such as ideologies (Goddard, 2002). What Laclau and Mouffe contribute to this historical perspective of hegemony is the introduction of key categories that facilitates an analytical framework for hegemonic transitions. Central to their thought is that a hegemonic transition is within the discursive field, in which particular social meanings can be identified and fixed to constitute hegemonic discourses, contingent upon the dominant narratives required by the ruling power of a state in different hegemonic orders (Laclau \& Mouffe, 2014; Ezzamel et al., 2007; Gleiss, 2015).

Since it is crucial to articulate such discourses in order to target disparate social groups with a view to forming a hegemonic bloc, Laclau and Mouffe borrowed the linguistic concept of the 'empty signifier' to envisage this articulation process (Laclau, 1996; Howarth, 2014). They argue that a hegemonic discourse as an empty signifier is tendentially emptied of content and therefore capable of adjusting its meaning to

\footnotetext{
6 The logic of class simplified the different identities and struggles of a society only to create a conflict between classes and prescribed classes or the interests of social groups according to the economic structure (Yang \& Tang, 2018).
} 
unite social groups for hegemonic change. An empty signifier also functions as a point of identification, by which diverse social groups, including those at the economic level, could position themselves within collective identities by crystallising particular meanings and interests (Thomassen, 2016). The articulation is complete when collective identities coalesce at a nodal point which turns an empty signifier into a privileged signifier representing the dominant hegemonic discourse. While the hegemonic discourse is always open to re-articulation, since hegemony is historically cumulative in nature, different meanings and identities can be fixed in the empty signifiers at different nodal points throughout the ongoing hegemonic process (Smith 2012; Laclau \& Mouffe, 2014; Gleiss, 2015).

The historical characteristic of hegemony is reflected in China's unique development path and is found in its political driven economic reforms ${ }^{7}$. In this sense, Laclau and Mouffe's concept of articulation is able to provide a holistic framework (refer to Table 1) with which to analyse China's economic development as a cumulative process of hegemonic building. Specifically, we contend that the discourse of "economic development" is a materialised ideology which is commonly accepted by different social groups to create a unified identification. As an empty signifier, "economic development" can be attributed different meanings and identities arising from adjustments in the hegemonic order, which is also capable of embodying itself at the material and economic levels in the form of different economic policies and mechanisms. Economic policies and mechanisms at different stages of economic reform thus operate as nodal points which crystallise and privilege particular meanings and identities in order to articulate the state's hegemony within its economic system. This enables us to further explain the experiences and actions of various players in articulating hegemonic orders with economic activities (Alawattage \& Wickramasinghe, 2008; Ashraf \& Uddin, 2015). In particular, we ask how the managers and directors of multinational SOEs identify their own roles/work within the prevailing hegemonic order of "economic development" and interact with existing accounting and control practices (Mantzari \& Georgiou, 2018).

\section{China's hegemony vs. international societies}

We identify Chinese multinational SOE as an important flagship of hegemonic articulation at the economic level, mainly because of its significance in China's economic reforms over the last decade. In particular, there has been a significant shift in national strategy from the domestic to the global market supported by government's OFDI and reflected in terms of the overseas expansion of Chinese stateaffiliated enterprises (Grimm, 2014; Wang \& Elliot, 2014; Huang, 2011). The "global

\footnotetext{
7 In particular, it is well-accepted that China's economic reform proposal in 1978 represented a reorganisation of the CCP's hegemony from a Soviet-like communist country based on economic planning and class struggles, to a socialist state with greater reliance on market-oriented 'economic development' policies and practices. The concomitant changes in accounting and control practices have been described as a representation of economic transition, reflecting the demands of maintaining the new hegemony at different times (Yee, 2009; Xu et al., 2013, 2014; Ezzamel et al., 2007; Yee, 2012; Su, 2011).
} 
rise" of China's economy since 2008 has resulted in debate and controversy ${ }^{8}$ in the areas of international politics and business studies (Buzan, 2010; Rucki, 2011; Strange, 2011; Zhang, 2018; Trindade, 2018), although there has been little attention from the accounting literature regarding this particular development. It is acknowledged that the unprecedented economic development of China has evolved from a domestic pursuit to one that seeks global impact through a so-called 'war of position' involving a "slow, hidden conflict, where forces seek to gain influence and power" (Peng, 2018, p. 53). This is further reinforced by China's increasingly assertive foreign policies, such as the One Belt One Road plan, as well as proactive adjustments in economic initiatives enabling China to take leadership and initiative on the world economic stage (Trindade, 2018; Overbeek, 2016; Nolke, 2015; Foot, 2006; Campbell, 2008). It would thus be relevant to take into account the rising international influence of China's intertwined politics and economy in our hegemonic analysis. In effect, the way in which the underlying hegemonic logic of recent economic reforms operates remains in question ${ }^{9}$ (Buzan, 2010; Strange, 2011; Zhang, 2017; Peng 2018) and, specifically, the way that such hegemony is articulated with economic activities (i.e. accounting and control practices) has not yet been investigated (Ezzamel et al., 2007; Yee, 2009, 2012; Xu et al., 2014, 2017).

In this sense, we sought to broaden our theoretical framework by re-envisaging the hegemonic construction of a state as the process of developing its relationship with international society, for which Cox's conceptual nexus of hegemony and international relations has been incorporated into our theoretical framework (Cox, 1981; Bieler \& Morton, 2004). As a neo-Gramscian, Cox advocates Gramsci's key thoughts about the historic bloc ${ }^{10}$ and argues that a hegemonic arrangement becomes configured by the specific context of a state and of its historical structure and political struggles. This suggests that the different forms of the state are the expression of particular historical blocs (Bieler \& Morton, 2003). More importantly, Cox argues that once the historic bloc of a state has been consolidated domestically, it can manifest itself as an international phenomenon, thereby outwardly expanding its hegemonic arrangement on the world stage (Saull, 2012). In other words, changes to international relations and the emergence of alternative forms of world order could be the result of the externalisation of a state's hegemonic project, which either challenges or adapts to the existing and dominant hegemony. Cox's conception provides an insightful lens

\footnotetext{
8 Some studies have espoused a positive attitude towards the increasingly influential role of China in international society and described China as a revisionist in the current world order, whilst others have treated China's global expansion as a threat to the current international society, which is dominated by a neoliberal hegemony, and questioned its sustainability in the long term.

9 Researchers criticised China's economic expansion as a means to maintain its socio-political stability and a pragmatic solution to over-accumulation in the domestic market. The main argument is around the divergence of the economic and political systems behind China's economic development and international expansion. Specifically, the way that a neoliberal, market-based economic sector created by the Chinese government is paralleled with and supported by relatively state-centred, one-party dominated protectionist political instruments.

10 Cox (1981) describes a historic bloc as the basis of shared social purposes where a variety of social groups and interests coalesce to promote not just a harmony of political and economic aims, but also wider cultural and moral unity on a "universal plane" (Gramsci, 1971; Morton, 2007; Saull, 2010).
} 
through which to understand China's increasingly confident economic and political policies in the international arena, by which our analysis of the historical structure of China's hegemony and its international expansion can be understood as reciprocal relationships between a state's ideation, material capabilities and institutions (Cox, 1981; Peng, 2018).

Firstly, Cox believes that the Gramsci's ideas of consent are not just nationalistic values and understandings of the hegemonic order, but also reflect the prevalent collective images of a world order (Bieler \& Morton, 2003, Cox, 1981). This understanding allows an outward look at China's ideological transition, in which the configuration of meanings and identities in the discourse of "economic development" reflects a hegemonic approach to engaging with, adapting to and eventually contributing to international economy, polity and society. Secondly, while Cox argues that such ideas are enabled by material powers such as resources accumulated internationally, they also manifest the importance and necessity of investigating the international economic activities of the state as a reflection of hegemonic externalisation. Lastly and more importantly, Cox's conception explicates the vital role of China's SOEs in understanding how changes in the hegemonic order have been articulated at the economic level in the form of the state's overseas economic policies and operations. While Cox emphasises that international institutions are amalgams of ideas and material resources for stabilising a particular hegemonic order at the international level, we contend that China's SOEs and their managers are the pivotal players in China's latest economic reform and the embodiment of China's hegemonic arrangement in the international arena. These managers have a specific identity and ability in articulating political hegemonic demands alongside economic ones, and we argue that they rely on accounting and control practices to help justify these demands.

Overall, and thereby departing from Gramsci's original notion of political hegemony, we adopt the neo-Gramscian notions of Laclau and Mouffe on hegemonic articulation and Cox's hegemonic internationalisation to establish a theoretical framework with which to analyse China's ongoing hegemonic process. This framework specifically enables an investigation of how the CCP's hegemonic visions and discourses are materialised into concrete economic activities and organisations, which in turn are intertwined with the Chinese state's political ambition in the global arena. This encompassing theoretical framework further allows a response to the current accounting research calling for an in-depth analysis of the political nature of accounting and control practices in China (Ezzamel et al., 2007, Yang \& Modell, 2015; Gong \& Cortese, 2017). Specifically, it allows us to investigate how accounting and control practices, as malleable objects, become purposefully deployed to cope with policy changes in the economy in line with the transformation of a state's hegemonic order. 


\begin{tabular}{|c|c|c|c|c|}
\hline Timeline & Before 1978 & 1978 - 1992 & 1992-2008 & After 2008 \\
\hline Hegemonic order & $\begin{array}{l}\text { Soviet style } \\
\text { Communism }\end{array}$ & $\begin{array}{l}\text { Socialism for } \\
\text { modernisation }\end{array}$ & $\begin{array}{l}\text { Socialism with } \\
\text { Chinese } \\
\text { characteristics }\end{array}$ & $\begin{array}{c}\text { Socialism for } \\
\text { harmonious } \\
\text { global community }\end{array}$ \\
\hline & Class struggle & \multicolumn{3}{|c|}{ Economic development } \\
\hline (empty signifier) & $\begin{array}{c}\text { Anti-capitalism and } \\
\text { anti-western } \\
\text { domination }\end{array}$ & $\begin{array}{c}\text { Pragmatic } \\
\text { developmentalism }\end{array}$ & $\begin{array}{l}\text { Reform and } \\
\text { opening up }\end{array}$ & $\begin{array}{l}\text { Peaceful rise of } \\
\text { Chinese dream }\end{array}$ \\
\hline $\begin{array}{l}\text { International } \\
\text { relations }\end{array}$ & $\begin{array}{l}\text { Isolating from } \\
\text { international } \\
\text { society }\end{array}$ & $\begin{array}{c}\text { Engaging \& } \\
\text { participating in } \\
\text { international society }\end{array}$ & $\begin{array}{c}\text { Adapting \& } \\
\text { integrating with } \\
\text { international } \\
\text { society }\end{array}$ & $\begin{array}{l}\text { Contributing to } \\
\text { international society }\end{array}$ \\
\hline $\begin{array}{l}\text { Economic system } \\
\text { (nodal points) }\end{array}$ & Central planning & $\begin{array}{l}\text { Dual pricing system \& } \\
\text { CRS }\end{array}$ & $\begin{array}{c}\text { Market } \\
\text { orientation \& } \\
\text { MES }\end{array}$ & OFDI \& Zou Chu Qu \\
\hline Overseas operations & Political task & Economic benefits & $\begin{array}{l}\text { International } \\
\text { cooperation }\end{array}$ & $\begin{array}{l}\text { International } \\
\text { leadership \& } \\
\text { influence }\end{array}$ \\
\hline Role of SOE & Unit of government & $\begin{array}{l}\text { Economic } \\
\text { responsibility }\end{array}$ & $\begin{array}{c}\text { Learning \& } \\
\text { experiment field }\end{array}$ & $\begin{array}{l}\text { Hegemonic } \\
\text { apparatus }\end{array}$ \\
\hline $\begin{array}{l}\text { Accounting \& } \\
\text { controls }\end{array}$ & Cheng Jian Zhi & Engineering norms & $\begin{array}{l}\text { Project budget \& } \\
\text { target costing }\end{array}$ & $\begin{array}{l}\text { Accounting \& } \\
\text { controls as part of } \\
\text { Ideology and } \\
\text { Political Work }\end{array}$ \\
\hline
\end{tabular}

Table 1. China's hegemonic progress, economic reforms and accounting and controls in SOE 


\section{Research case, design and methods}

We focus on the construction industry in view of its determining role in the Chinese national economy and of its significance worldwide. The long-standing involvement of the state in this sector facilitated our research into the evolutionary nature of China's economic reforms, because the development path adopted by the Chinese construction industry has tended to reflect a step-by-step response to state reforms and policies over time (Chen, 1998; Corkin, 2012). As an illustration, Chinese construction enterprises were one the earliest participants and beneficiaries of overseas endeavours due to the diplomacy-led aid-project policies in developing countries, including African ones, since the 1960s (Kernen \& Lam, 2014). Taking into consideration this historical context and experience in overseas operations, the interactions between contextual factors and managerial values/perceptions, there is scope to enrich conceptions of the multi-faceted role of accounting and control practices in emerging and developing economies. At the same time, a hegemonic and processual analysis of accounting and control practices admittedly comes with particular challenges. Firstly, a longitudinal research design would certainly enable a deeper appreciation of the junctures and/or critical events pertaining to shifts in the hegemonic order and the concurrent implications for managers as they seek to adjust or respond to the new imperatives. Such a design would be challenging to implement over time, however, given the very politicised and hegemony-building context in which the researcher(s) need to interact with research informants and organisations over a relatively extended period of time. Secondly, how does a particular hegemonic order become 'articulated' at the economic base (e.g. level of managers, institutions), which is in a given international arena (e.g. a foreign subsidiary), can vary considerably. In effect, we can only offer a 'snapshot' (in a given time and space) of events at the economic base whilst recognising the dynamic nature of the hegemony building process.

Our empirical material relates to International GS, a subsidiary of a large state-owned construction group company (Construction GS) in western Mainland China. It was established in 2010 as part of the efforts to restructure the development pattern and readjust the industrial structure of construction SOEs towards global market expansion. International GS has two group subsidiaries in Ghana and Zimbabwe, which are responsible for construction projects in more than 16 African countries (see Figure 1).

Our field study focuses on the company's headquarters in China, GSLZ, and the Ghanaian subsidiary, GSJN. We selected these two research sites because, on the one hand, GSJN is one of the biggest overseas subsidiaries of International GS independently registered as a company in Ghana, conducting construction projects and other diversified operations in many other African countries. On the other hand, GSLZ, as the head office, supports and monitors the operation of GSJN by designing accounting and control rules for overseas operation, setting profit objectives, arranging key personnel, and dispatching construction supplies. 


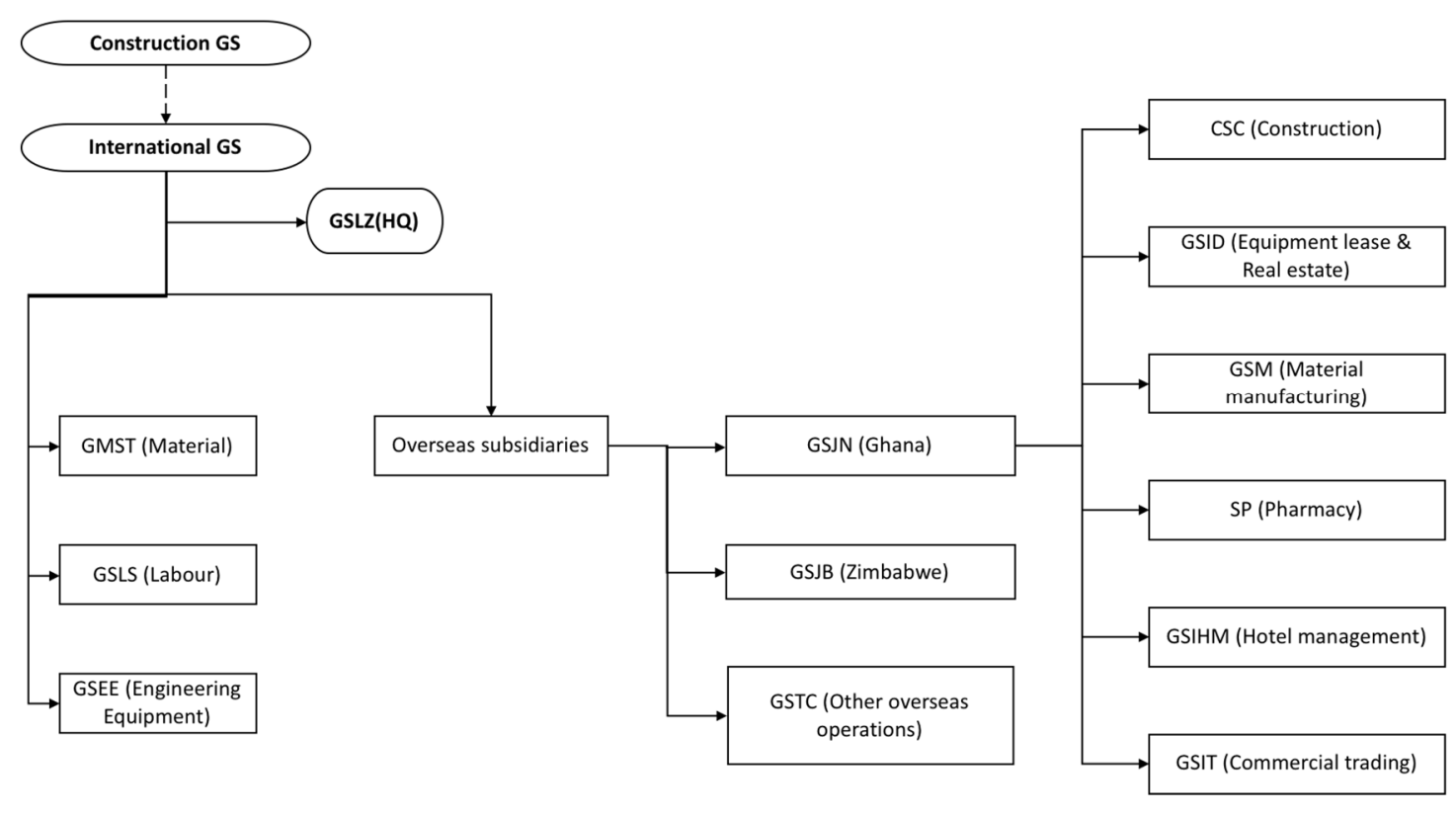

Figure 1. Organisational structure of International GS

The first author (who is a Chinese native) spent two months conducting interviews and documentary reviews relating to the development of International GS and the design of accounting and control practices for overseas operations at GLSZ. This field trip eventually facilitated accessibility to the GSJN field during a three-week field visit to gather first-hand data about the accounting and control practices in 'real' overseas operations. GSJN's closed and self-sufficient work environment (a building complex with strict entrance control, comprising offices, accommodation, dining hall and leisure facilities) benefited our data collection because the researcher worked and lived together with the company staff during the field visit. Data was collected informally (e.g. observations; conversations) in addition to the formal interactions. Overall 47 semi-structured, formal interviews lasting between one and two and half hours were completed ( 20 in GSLZ and 27 in GSJN). These interviews involved company supervisors, department directors, middle level managers within departments, and particularly the directors of local subsidiaries and Ghanaian managers in GSJN. Appendix A provides a detailed interviewee profile for this case study. Most managers required interviews to be recorded through note taking rather than audiotaping due to commercial confidentiality and sensitive issues relating to SOEs.

In addition to interviews, a wide range of documents, including International GS's development chronicle, annual meeting summary and report, management manual and other published materials relating to China's economic reform and the history of China's construction industry, were also reviewed. We also mapped the development of the accounting and control practices in relation to the changes in organisational structure and strategy, and policies. In addition, we relied on the management manual compiled by GSLZ, which explicitly listed managerial rules and regulations for every single functional department of GSJN.

The data collected from the field study was analysed through a step-by-step thematic approach (Braun \& Clarke, 2006). The transcriptions and field notes of interviews 
include both English and Chinese versions and most of the latter (33 of 40) were sent back to the relevant interviewees for re-examination and feedback. The improved transcriptions were reviewed and coded using an open-ended strategy (O'Dwyer, 2004) to capture any possible meanings, which were then combined and classified into eight first-step themes: 'politics', 'economy', 'construction', 'overseas', 'strategic concerns', budget control', 'cost control' and 'managers perceptions'. Meanwhile, based on the review of archives, we drew a timeline of China's political and economic reform from its establishment in 1949, within which we highlighted significant changes in each developmental stage (pre-1978, 78-92 and after 1992) and classified them into a topdown order consisting of themes such as "political ideology", "economic system", "industrial characteristics", "SOE development" and "overseas expansion". We then mapped the first-step interview themes with the themes identified from the review of reforms, wherein repeated themes were merged and refined and new themes identified. Five second step themes, "strategy", "design of accounting and control", "ideological and political work", "project budget" and "target costing," were identified and used as the main topics for data presentation. By incorporating case data with the historical review, we were able to provide an analysis of each topic from both a 'topdown' and a 'bottom-up' perspective, which further cascaded the hegemonic analytical framework from political and ideological work at the national level (represented as economic reform) to hegemonic construction at the organisational level, as well as the effects on, and response from the agents and practices within the organisation.

\section{China's hegemonic progress, economic reforms and International GS}

\section{Soviet style Communism - Prior to 1978}

The foundation of the People's Republic of China (PRC) in 1949 proclaimed the establishment of the Chinese Communist Party's (CCP) regime in Mainland China. As the ruling force of China, the CCP's governance was fundamentally built on MarxismLeninism principles which put a primary focus on class struggle between the proletariat and the bourgeoisie, so that public ownership was advocated as an imperative to eliminate exploitation and class differences (Chen, 2009). The dominance of public ownership further paved the way to adopt communist socioeconomic practices, and particularly an economic mode of central planning and production inspired by the Soviet Union. This economic mode emphasised the state as the central planner, with a top-down administrative chain of command, as a result of which enterprises and other economic units were steered like divisional administrative units, complying with instructions, tasks and personnel arrangements from their parent ministry to aim for and achieve planned production targets; with little consideration of the economic consequences.

Underlying the political and economic systems was the CCP's aim to achieve a communist "new China" with an attitude of rejection and hostility towards capitalism and imperialism. As a result, China assumed some responsibility for proletarian world revolution by supporting political struggles and providing economic and technical assistance to revolutionary parties and governments in less-developed countries in 
Southeast Asia and in Africa (Corkin, 2012; Peng, 2018). While this political standpoint inevitably isolated China from the international society dominated by western capitalist countries, the diplomatic policy of foreign economic aid was recognised as an important means to ensure the worldwide diffusion of China's communist ideas and values (Buzan, 2010). This political significance made the government extremely cautious and selective when allocating economic aid projects to enterprises. Political and ideological 'correctness' was emphasised as a basic premise, for which people involved in aid projects must adhere to a firm patriotic belief that working on such projects contributed to the national interest, and namely towards the international emergence of a communist China (Xu et al., 2014).

This political imperative led SOEs, particularly those in the construction sector, to develop qualified teams to carry out construction aid projects in selected countries. As a result, the implementation of Cheng Jian Zhi was examined as the main way to identify qualified working teams. As a military terminology, it described a fixed team of organisational members with complete sets of specialties, a clear division of labour, strict discipline and unified action. The use of Cheng Jian Zhi not only prescribed the role of each individual in engineering and construction, but also emphasised a centralised approach to administration, in which a collective staffing structure and deployment coupled with a high level of compliance to commands were essential for the fulfilment of production plans. In other word, Cheng Jian Zhi represents a reinforced discipline of compliance, a sense of unity, militarised management mode and political recognition. The excellent execution of 'Cheng Jian Zhi, meant that Construction GS, as the parent of International GS, was one of the earliest SOES qualified to conduct aid projects in Africa. Many construction projects, including parliament houses, embassies, national stadiums and theatres, were commissioned from the 1970s. This success with aid projects was well recognised by African governments, which paved the way for Construction GS's further expansion into the African market.

\section{Socialism for modernisation - 1978 to 1992}

While the CCP's political initiatives aimed to achieve an alternative form of modernity and development that sought to bypass capitalism, the exclusive reliance on radical revolutions, such as nationwide class struggles and political campaigns, led to not much more than social instability and poverty ${ }^{11}$. As the party's successor, Deng Xiaoping realised that the CCP's dominance could only be stabilised if the material interests of the masses were acknowledged. Class struggle was immediately abandoned in 1978 and replaced by new political mottos (Yee, 2009): downplaying abstract ideological quarrels, solving problems and testing theories via concrete social practices (shi shi qiu shi), and liberating people's minds from indoctrination to explore

\footnotetext{
${ }^{11}$ In 1959, Mao forcefully initiated the "Great Leap Forward" in order to catch up in a short time with Great Britain and the United States in relation to the level of industrialisation (Li \& Yang, 2005). This unrealistic campaign resulted in deteriorating economic conditions and the masses suffered from extreme poverty and hunger. The situation was worsened in the aftermath of the Cultural Revolution in 1966 when production and economic development stagnated as class struggle became the most important part of people's daily life. This devastating social movement did not end until Mao's death in 1976.
} 
new paths and experiment with new ideas (jie fang si xiang). These practical guidelines comprised Deng's concept of "building socialism with four modernisations; an encompassing socialist construction to provide a better material life for its people by rejuvenating the state's key fields of agriculture, industry, defence, and science and technology (Yee, 2009).

The economic system thus became the main 'battlefield' for achieving modernisation targets, starting with China's prolonged economic reforms. As an evolutionary process, the main thrust of these early stage reforms (1978-1992) was to justify economic development as the primacy of socialist modernity, for which a pragmatic approach was encouraged to introduce market mechanisms as a complement to existing economic planning, without considering its underlying ideological designation (Ezzamel et al., 2007; Chen, 2009). This inclusive developmentalist idea was reflected in the dual track pricing system. This system prescribed the coexistence of two prices for the same resource, whereby one represented a state-set price for the delivery of the planned production, and the other one represented the market price for the remaining part of production sold to the market. The political shift of focus from class struggle to domestic economy also demonstrated China's return to international society, whereby China's revolutionary resistance to the West was abandoned and replaced by a milder political view, emphasising co-existence within the status-quo of international society dominated by US hegemony. Capitalist metrics were encouraged to support socialist China's development, although such engagement was only allowed in economic areas (Zhang, 2017).

Due to the dominance of public ownership entities within the economic base, the SOE has been recognised as the key test bed for piloting market-led ideas. One of the most profound reforms for SOEs was the implementation of a Contracted Responsibility System (CRS), which sought to design a contractual relationship between the government and the enterprise, whereby the latter could negotiate with the former to prescribe a fixed target for profit generation and tax delivery, and retain the remaining surplus. SOE managers and workers were motivated by this, since their income and bonuses were directly linked to production. This idea of 'contracting' offered managers greater autonomy in construction project management (e.g. resource allocation, financial and cost controls, and labour distribution), which particularly benefited overseas projects since enterprises such as Construction GS were able to contract with overseas governments independently and take full responsibility in terms of the quality and profitability.

These favourable market-led approaches contributed to the rapid expansion of Construction GS in the African countries, by establishing local offices in Zimbabwe and Ghana in 1988. The enterprise still relied heavily on the Chinese government's endorsement and political assistance, however, in order to access and maintain overseas markets. This led not only to profit sharing arrangements between government and the enterprise, but also strict compliance with the government's control mechanisms, such as engineering norms. As a practice of the dual pricing system in the construction industry, the 'norm' refers to a unified and centrally controlled price and technical measurement over construction expenditure in terms of the unit price of material, equipment and labour usage (refer to example in Appendix B). This unique practice profoundly affected the operation and management 
of construction enterprises, since it determines the calculation of construction quantities and the pricing and bidding process (Chen, 1998; Sha, 2004).

\section{Socialism with Chinese characteristics - 1992 to 2008}

Driven by Deng's idea of 'fact-based experimentation', China's early stage economic reforms have often been described as "government-sponsored pilots" where policies and practices were carried out on a basis of trial and error (Lieber, 2013). This experimental approach inevitably led to detrimental consequences which jeopardised the CCP's political legitimacy ${ }^{12}$ and questioned its ability to steer economic reforms (Xiao, Weetman and Sun, 2004). Chinese society was in stagnation until 1992 when Deng made his famous "South China Tour" to restate a determination to build a socialist country with 'Chinese characteristics' based on the CCP's leadership and market-based economic reforms and opening up ${ }^{13}$. While the 'Chinese characteristics' tended to be explained contingently upon China's development progress, it downplayed the superiority of socialism and acknowledged the long-term coexistence of China and western capitalist countries within a status-quo international relations and governance system. This renewed diplomatic strategy was clearly reflected in the political discourse of "Tao Guang Yang Hui" proposed at the beginning of the 1990s (Peng, 2018), which marked domestic development and economic modernisation as priority national interests, but at the same time it demanded that the country keep a low profile and be restrained in the international arena. This political adjustment suggested that the CCP's intention was to adapt with and integrate into the status quo of the international order by accepting and complying with western-led rules and ideas (Buzan, 2010; Strange, 2011).

As a result of Deng's philosophies, economic reforms re-started in a more intensive and market-oriented way. "Planned economy" gradually disappeared from state propaganda and was replaced by the "socialist market economy" (Xu, 2011). The later Opening Up policy further encouraged the introduction of Western-based economic theories and market concepts, and various new market and institutional mechanisms such as corporatisation, privatisation, shareholding and international joint ventures were piloted with overt political support. Economic reforms became acceptable and appreciated by the masses because the development of different forms of 'somewhat' private ownership mobilised the Chinese people to participate in the economic

\footnotetext{
12 For instance, the lack of surveillance mechanisms in CRS and dual track pricing system aggravated nepotism, corruption and the abuse and loss of state assets (Huang \& Duncan, 1997; Yee, 2012; Hassard et al., 2010). The masses' grievances and anxiety with economic reform, along with the appeals for political transparency, greater accountability, and freedom of the press and speech, eventually led to a radical social movement - the Tiananmen Square protests of 1989, which had to be forcibly suppressed to restore social stability.

13 Deng unprecedentedly divorced economic mechanisms from their inherent ideological assumptions, whereby any means can be mobilised to serve socialist productive needs, without paying attention to lofty theoretical, philosophical and ultimately unproductive debates. As his speech stated: "Planning and market forces are not the essential difference between socialism and capitalism. A planned economy is not the definition of socialism, because there is planning under capitalism; the market economy happens under socialism, too. Planning and market forces are both ways of controlling economic activity. (Deng, 1992)".
} 
transition. This ensured that "developing the economy" became an important idea in people's daily lives (Su, 2011).

China's entry into the World Trade Organisation (WTO) further reduced barriers to international trading, cooperation and knowledge transfers with the rest of the world. In facilitating better international cooperation and integration, the Modern Enterprise System (MES) policy was proposed to promote scientific management mechanisms, improve technical transformation and implement various means of property rights and asset reorganisations. This policy was primarily piloted in SOEs which dramatically changed their organisational structures, and some half had become shareholding enterprises by the end of 2008. Driven by the MES-based restructuring of SOEs, Construction GS experienced a dramatic corporatisation process from 1994 to early 2000s. The enterprise was re-organised into a provincial shareholding SOE in 2001, which led to increased autonomy, particularly in designing and implementing management mechanisms for its overseas operations. As a result, many modern project management techniques were adopted, which included standardised project procedures and regulations, clear managerial responsibilities/boundaries, and advanced accounting and control practices such as project budgeting and cost management.

\section{Socialism for a harmonious global community - 2008 to the present}

While China enjoyed unprecedented economic success after its marketisation and opening up policies, the runaway economic growth in the recent two decades has led to domestic issues such as a worsened environment and pollution, large wealth gap and social inequality, which might be potential causes of social and political instability. In order to mitigate these negative impacts, the CCP promptly renewed its political discourse as "building a harmonious socialist society". This suggested a heightened consideration of the overall societal balance and harmony around the major economic reform policies for socialist development. The concept of 'harmony' soon extended to an international dimension, namely a "harmonious world for the community of common destiny" (Zhang, 2018). These discourses sought to portray the world as the common community of all humankind, who should work together cooperatively and peacefully to achieve the common goal of world prosperity, regardless of national and ethnic differences. Central to this grand picture is the proactive expression of the willingness and responsibility of the Chinese government in leading and contributing to regional/global public goods in the new era of socialist development of China.

This political redirection has been projected onto economics and resulted in Sinocentric economic and development systems and institutions such as the expanding Shanghai Cooperation Organisation, the founding of BRICs New Development Bank and the One Belt One Road initiative (Campbell, 2008; Zhang, 2017; Trindade, 2018). While it is argued that these outward-looking economic initiatives were designed to maintain China's economic growth and to address wealth and production overaccumulation in the domestic market, they also politically conveyed the image of a responsible and peaceful rising superpower, calling for international partnership with "wide consultation, joint contribution and shared benefits" (MOFCOM, 2017). Such international prospects have been publicised to Chinese people alongside a "Chinese Dream", concerned with the national ethos and ideals, such as Chinese prosperity, 
collective effort, socialism, national glory, and eventually the revitalisation of the nation in the international arena (Wang, 2014).

At the same time, this discourse of intensified economic transitions should not be seen as an acceptance of the capitalist liberal economy. Political-led OFDI has become one of the most important approaches to exercising international economic initiatives for which Chinese SOE has always been the first point of contact with other players in the neoliberal-based global market, however, state control remains ubiquitous, albeit evolved into more implicit and focused mechanisms (Chen, 2009). For instance, the National Commission for Development and Reform (NCDR), founded in 2006, is responsible for devising five-year national economic plans, although these 'plans' are now announced as prospective guidance rather than a mandate. The enterprises' obedience to government policy is encouraged because political support, protection and benefits are expected as a return on this obedience. The state-owned Assets Supervision and Administration Commission (SASAC) was established as a specialised third party for supervising and guiding the major decisions and activities of SOEs. Although the state appeared to visibly withdraw from the running of operations, central control over SOEs was tactically preserved via SASAC's political instructions embedded in performance evaluation benchmarks, personnel appointments and employment rules, and the enterprise's investment proposal (Firth, Fung and Rui, 2006; Chiwamit et al., 2014). The establishment of a 'party branch' in each SOE further asserted the CCP's leading position as the enforcer and guarantor of the SOE'S development. As a unit operating in parallel with the new business structure, the 'party branch' reflected the managers' dual identities in SOEs, since managerial positions/appointments needed to be validated by corresponding authorities within the Party's hierarchy (Scott, 2002).

These changes reflected the CCP's strategic redirection in the function of SOEs in the international economy. Economic initiatives professed by the NCDR and SASAC indicated a change in the state's role, from 'controller' to that of investor and shareholder of SOEs. The state-led development model was extended to overseas markets under the CCP's proposal of Zou Chu Qu (going outside); an improved version of the Opening Up policy promoting China's industries and enterprises via international trade and cooperation, export and import and overseas investment and operations. The construction industry was recognised as an exemplar with which to pilot Zou Chu Qu, mainly because of its previous experience in aid projects. In 2010, the central government proposed the "Special Issue of Twelfth National Five-year Plan (2011-2015) for Construction Industry", within which an ambitious economic goal (15\% increase of annual output) was set for the industry and highlighted that the achievement of such target would rely greatly on overseas expansion driven by China's ODFI. This plan also asserted the industry's significant role in driving China's exportled economic growth, since increased overseas construction projects typically provide other industries with more opportunities for international trade. Consequently, the central government also instructed overseas SOEs to explore and conduct diversified operations based on host country conditions, to help bridge trade opportunities between overseas markets and China's domestic manufacturing and service industries. 
In response to the government's increasing demand for SOE overseas expansion, Construction GS was restructured into a group corporation with renewed strategies ${ }^{14}$. As a result, International GS was established in 2011 to manage and conduct overseas operations on behalf of Construction GS. While the strategic shift also reflected top management's concerns about saturation in the domestic market, the decisionmaking was primarily motivated by political reasons since strategic adjustments and the following restructuring of International GS reflected the government's change of tack. Specifically, International GS consists of three domestic sub-companies (GSMT, GSLS, and GSEE) as the support and service centres for providing material supply, labour service and equipment allocation for overseas centres. 'Diversification' was extensively practiced in local subsidiaries such as GSJN. While three of the six subsidiaries in Ghana focused on the construction industry (CSC for building construction projects, GSID for equipment leasing and real estate development, GSM for concrete processing and brick manufacturing), GSJN also reached other industries in terms of pharmaceutical manufacturing (SP), commodity trading (GSIT) and hotel management and travel agency (GSIHM).

\section{Hegemonic discussion of the Economic reforms}

As part of the CCP's evolutionary hegemonic building process, China's political transition from the foundation of the state in 1949 to the present can be categorised into four hegemonic orders, each with a political agenda and associated discourse(s). Overall, this process was initially an active response to the political crisis that emerged from the Communist period (1949 - 1976), with an emphasis on class struggle and Soviet-like domination. The socialist adjustment since 1978, proposed in the aftermath of the political turmoil, were an attempt to restore the CCP's legitimacy by re-orienting the party to a consent-based hegemonic governance which considered the common interests of the masses and the material demands of different groups. Since then, the CCP's hegemonic construction has always been centralised around the fundamental idea of socialist development, accompanied by political appeals ranging from 'modernisation' to 'Chinese characteristics' and on to 'harmonious global community' (Zhang, 2018). These reflect timely adjustments to the CCP's hegemonic order in response to the economic progression of domestic China, and the need to adopt an increasingly influential role in the international arena.

This hegemonic pathway resonates with the findings from previous studies in China (Su, 2011; Lieber, 2013; Ezzamel et al., 2007; Yee, 2012), wherein ideological transitions gradually made "market oriented economic development" the dominant ideology in China. The ideological term "economic development" has been effectively used as an empty signifier (Laclau \& Mouffe, 2014; Howarth, 2014; Thomassen, 2016), and its meaning was constantly revised and modified to adapt o political needs under different hegemonic orders. For instance, "economic development" was initially

\footnotetext{
14 In its 'Ninth Five-year Summary Conference' in 2012, the chairman of Construction GS explained that new strategies represent the resource reallocation by which the construction business will be complemented by diversified operations in terms of real estate, technical consultancy, project design, engineering manufacture and new material development. It also shows a willingness to expand overseas operations as one of the three major sectors of group business and source of profit, in which $40 \%$ of overall revenue is expected to be generated from diversified operations.
} 
portrayed as the means to achieve modernity and prosperity and thus direct people's focus away from class struggles (1978-1992). 'Economic development' was then endowed with the idea of openness to facilitate domestic developments and China's smooth integration with the international order (e.g. World Trade Organisation) and its underlying capitalist ideas (1992-2008). While China began to demonstrate its global influence and leadership (from 2008), "economic development" then became the determinant intermediary of this transition, and also a platform where an individual's quest for achievement and the national interests coalesce (the Chinese Dream) to deliver the renaissance of the nation.

Selecting the economic domain as the main field of ideological diffusion is arguably the key to the success of CCP's hegemonic building. It provides a concrete workplace facilitating individual participation and then forming consent (Su, 2011; Lieber, 2013). Arguably, the masses can more easily perceive and be influenced by changes in the economy because of the closer and significant relationships between the economic system and people's daily lives and material interests. The economic domain is also the most accessible and actionable field in which common people participate, where the increase in personal wealth and improved living conditions could reinforce people's confidence and belief in "economic development". In this sense, the ongoing economic reforms were not merely changing aspects of the economy, but also led to a moral and intellectual process seeking to materialise the CCP's political ideology (Gramsci, 1971). The CCP, based on its policy making and adjustment and pervasive propaganda, mobilised the masses to take part into the invisible economic battlefield as part of their normal practices; and the party itself was positioned as the moral and intellectual leader determining the parameters of the battle (Yee, 2009; Ezzamel et al., 2007).

From an economic perspective, changes in the hegemonic order were mainly manifested in the party's compromises and accommodations, which were articulated during the key nodal points of China's economic mechanisms (Thomassen, 2016; Gleiss, 2015). This was primarily tested in SOEs with a focus on the mode of interest sharing (e.g. CRS and dual track pricing). Economic interests were further shared with enterprises and managers when market mechanisms in terms of shareholding were promoted by the CCP's Opening Up policy (after 1992). When greater attention was required to the benefits from international markets, SOEs were encouraged and motivated to seek profit in foreign markets. As a result, multinational SOEs such as International GS emerged, by which the government's macro-economic deployment such as Zou Chu Qu became internalised as part of the enterprise's strategic directions of diversified operations and localisation. The increased benefits and interests improved the SOE's ability to advocate the government's political and economic initiatives, which in turn enhanced the CCP's hegemony because of the SOE's leading position and decisive effects on China's economy and society.

The interactive relationship between the CCP, SOEs and Chinese economy reveal a path of hegemony building that is different from Gramsci's traditional thoughts, which focused on consent within civil society under modern capitalist societies (Goddard, 2002, 2005; Yee, 2009, Xu et al., 2013, 2014). In China, 'consenting' SOEs and their managers play a significant role in aligning the CCP's political appeals to the demand of the masses, and articulating such hegemonic conditions into a material and 
understandable form, namely a representation of "economic development". The CCP, as the dominant structure of the authoritative state, strategically used its coercive mechanisms (SASAC and NCDR) to set a baseline for the consent-based hegemony. In other words, the SOEs are able to operate autonomously in the pursuance of institutional and managerial self-interest, as long as the assigned political tasks are fulfilled, and predetermined 'boundaries' are not crossed. This intermeshing of coercion and consent suggests that China's hegemony is built on a uniquely interdependent and reciprocal relationship between the CCP and its SOEs. While the CCP relies on the economic performance of SOEs for diffusing and claiming political legitimacy, SOEs behave somewhat obediently to political instructions in exchange for better resources and business opportunities.

China's political evolution, along with its economic reform, further revealed a clear roadmap of the CCP's internationalisation of its hegemony to the status quo of the international order, which is particularly manifested in recent decades, shown as increasingly proactive political discourses and proposals, the emergence of China-led international institutions and the expansion of Chinese multinationals driven by the government-based OFDI. A fundamentally different logic that distinguishes China's hegemonic expansion from the western mode (e.g. US hegemony), however is its exclusive focus on the economic perspective. Underlying China's reciprocal propaganda of "harmonious world community" is the expectation of the peaceful rise of a socialist country with integration into the modern market economy, whilst keeping itself away from the potential risks of political and cultural convergence with the democratic facets of neoliberal capitalism (Strange, 2011; Buzan, 2010). While this has been criticised as a pragmatic approach that seeks to take advantage from both sides without shouldering relevant responsibilities, whether and how this mode has been exercised in the economic practices remains questionable. We can therefore now provide a 'grounded' explanation of China's hegemonic externalisation by investigating how the current hegemonic order (termed Socialism for harmonious global community) is articulated within a multinational SOE. We thus move on to the case study with a particular focus on the accounting and control practices that embody this form of dynamism in the most recent variant of China's hegemonic order.

\section{Accounting and control practices in International GS}

\section{'Modern' accounting and control practices in International GS}

There has been a consensus among senior managers since the establishment of International GS, that developing 'modern' accounting and control systems was essential for achieving the enterprise's international strategies. The CFO of GSLZ (the headquarters) explained:

"...ten years ago we could achieve a higher profit in overseas projects because of the cheap materials and labour forces from China, but the price differences are disappearing and nowadays we are competing with Americans, Europeans and Ghanaians and profit is relying on efficient cost control, reduced internal frictions and advanced project management..." (LZ5)

As a result, a uniform managerial manual was developed by GSLZ which includes detailed standards, rules and regulations covering most aspects of overseas operations, 
such as job responsibility for managerial positions, project contracting and construction methods, material procurement, personnel management and salary management. This 'rule-based' system was believed to be "the cornerstone for establishing a modern, market-oriented enterprise" (LZ1), which was greatly encouraged by the central government's policies of establishing MES in the new era of China's hegemonic expansion in the global economy. The deputy general manager of GSLZ commented:

"...the government's MES policies made us more determined to get rid of the chronic illness of SOE management such as 'discretion' and 'arbitrariness'. It is particularly important for our overseas operation as we are required to learn from modern business and develop appropriate management system to face the challenge from the international market..." (LZ2)

When considering the above, it was noted that the manager sought to frame the new modern enterprise system as one that conveyed the state concerns with mismanagement and managerial practice during the previous periods of economic reforms. In response to the increasing demand and pressure from the international markets, developing budgets at the project level was emphasised as one of the most significant practices in order to exercise MES policies in construction SOEs, as one manager stated:

"... (project budget) is the best representation of our changed role from the domestic to the international market. It allows us to have an enterprise-level target and plan to set our own price for construction projects, in other words, more managerial autonomy and economic responsibility in the competitive market." (LZ13)

The adoption of project budgets is further highlighted as an alignment with the international bidding system based on the approach of 'listed quantities'. This approach prescribes a quantitative list of the labour, materials and procedures involved in a project and asks each bidder to provide its own prices for the listed items. Bidders can only gain advantage by offering competitive unit prices, which directly originate from the company's budgeting system, thereby showing its capacities for management, resource allocation and market research. For International GS, the budget is not only a technical enactment of the economic consequences of a given activity, but rather helps ensure that the company is eligible to compete in international construction markets. The general manager of GSJN remarked that:

"Ghana follows the western way in legislation, political and economic systems and management modes, therefore, the establishment of a project management system is not just for managerial purposes, it is also an accredited means which improve local acceptance of our company, and it is also a specialty language for communications." (JN6).

Along with the introduction of a project budget there was a renewed emphasis on cost management. Inspired by the notions of target costing, GSLZ established a unified framework for each of its overseas subsidiaries, in which a detailed set of rules and regulations were prescribed to categorise cost management into three sections, namely 'ex-ante cost estimation', 'in process cost accounting' and 'ex-post cost settlement'. This approach was meant to ensure consistency with the normal flows of a construction process under international standards and a reflection of the SOE's 
commitment to adapt to international working practices. Specifically, cost estimation is carried out during the bidding stage to support the setting of price and cost targets. Cost accounting methods for timely examination and adjustment during the on-site construction stage are then conducted for the realisation of cost targets. Finally, managers and accountants revise cost target achievement, provide reflective reports and apply remedial work (if necessary) during the completion stage.

The use of target costing was recognised as an effective means by which to achieve modern international project management, since it helps an enterprise to set and communicate specific procedures, responsibilities and boundaries of cost control with each independent project, as one director highlighted in a quarterly management meeting:

"... each project team must set a clear target of cost management, and make sure everyone within the team understands and agrees with such a target. It (target costing) is not just about cost, but a new logic of management focusing on an individual's responsibility and motivation. It is the method a multinational should have" (JN8)

It is hard to conclude that the adoption of such accounting and control practices was a completely business-minded decision in response to international competitive pressures, however. Instead, these practices were greatly promoted by state-backed industrial associations and professional bodies, and driven by its underlying hegemonic appeals (Huang, Lai, Kao and Chen, 2012). For instance, the project budget was not substantially adopted until China's entry into the WTO in 2001, when the Construction Project Management Committee (CPMC), founded by central government, started to instruct and promote globally recognised project management rules and methods (Chen, 1998). In addition, the adoption of target costing in the construction industry was the result of a nationwide campaign driven by the state council's propaganda and promotion of the 'Han Dan' experience ${ }^{15}$. For many top managers in International GS, the changes to, and adoption of, accounting and control practices were mainly seen as 'political' tasks and in fact, even an obligation, since they were part of a leading SOE. A deputy general manager of GSLZ added:

"Our company (International GS) is a model SOE in Western China and because of this we are always expected to be in line with governmental willingness by carrying out assigned policies promptly and conscientiously. From the operational perspective, this means to respond to the government's call to adopt modern management systems and techniques such as project budgeting and costing. It is not only the main criterion of our performance assessment, but also determines the company's future development." (LZ3)

\footnotetext{
15 In the 1990s, Han Dan Iron and Steel Company (a large SOE) successfully implemented a responsibility cost control system including target costing in its control package (Lin \& Yu, 2002). This sheds a light on the managerial innovations in SOEs, which were crucial at the time when most SOEs were starting their restructuring process. As a result, in 1996 the State Council made an officially announcement promoting the 'Han Dan experience' to nationwide SOEs. Learning from 'Han Dan' was recognised as a politically correct practice, as Vice Premier Wu Bangguo defined 'in-depth learning from Han Dan management' as a central government's assignment for SOEs (see http://cpc.people.com.cn/GB/64184/64186/66687/4494370.html for an extract of Wu's speech).
} 
The development of new management, accounting and practices is thus one of the examples of how the CCP's hegemonic building process were materialised in the economic base via the powerful apparatus and political affiliation of the SOE. The case findings also reveal the dual identities of top SOE managers, at both head office and overseas subsidiaries levels, which facilitated the adoption of 'state-encouraged' accounting and control practices. Specifically, these managers were not only board members of their parent SOE (Construction GS), but also members of the CCP Committee of International GS. The managers' political ties to the government and Party prompted them to respond quickly to the proposals, so that the enterprise was able to align with the CCP's hegemonic deployment of economic reforms over time. In other words, SOE managers, with their unique identification and capabilities, ensured that they played a determining role in forming and maintaining hegemonic blocs (Gramsci, 1971; Cox, 1981; Bieler \& Morton, 2003), and articulating hegemonic arrangements using managerial activities.

The government also relied on leading SOEs such as International GS to showcase and provide feedback on new accounting and control practices before their wide dissemination to other SOEs and the domestic market (Li \& Belal, 2018). As the general manager of GSLZ recalled:

"Thinking back to the 1990s, we were like 'crossing the river by feeling the stones' while exploring the way to operate in overseas markets, and fortunately we finally found the 'stones' by learning and even copying methods and notions from well-performing enterprises, no matter whether they were Chinese or not... For the past 20-odd years we have been the experimental field for new ideas and methods. It is challenging but it is the reason why SOEs are always at the front line between the foreign and domestic markets." (LZ1)

This sense of mission, along with the rapid adoption and acceptance of accounting and control practices, suggests the crucial role of this SOE in building a foundation for the externalisation of China's hegemony. Through years of learning and development, these SOEs have not only contributed to economic accumulation in the domestic market, but also built a reputation and favourable image in the international economy, and thus becoming fully prepared to support China's latest hegemonic arrangement for international influence and leadership. For International GS and its managers, such hegemonic dynamism was further manifested in implementing these accounting and control practices in the workplace, although they appear to have been used in a rather selective or sometimes conflicting way. This is discussed further below.

\section{Engineering norms \& Cheng Jian Zhi}

While the project budget has been officially adopted as an 'essential' and 'modern' accounting practice with which to underpin modern project management systems, a somewhat unexpected empirical finding (given China's emphasis on detailed rules and procedures) was that there were very few detailed rules and little guidance on how to prepare the project budget. When prompted about this, some managers argued that preparing enterprise-level budgets is not at the top of their to-do lists because a benchmark of prices and costs is already available. As the director of GSEE explained: 
"...in China, construction is still being classified as a national strategic industry, which means government sets the prices for the resources involved in construction work activities. Therefore, our attention is given to an examination of the construction quantity as the basis for pricing, and how you organise your resources, labour forces and on-site work during the construction..." (LZ11).

This argument reflects the fact that engineering norms practices are still extensively used for project budgeting in International GS, although this government-led fixed pricing system has been downgraded from a governmental mandate to policy guidance in the domestic market. While International GS repeatedly emphasised the importance of modern project management and actively participated in the international bidding process, the adoption of project budgeting was thus rather superficial because it failed to establish enterprise-specific prices and costs. The insistence on maintaining the engineering norms arose from the manager's own view that:

"...we have to follow the international rules by giving a 'market' price to complete the bills of quantities; however the price was really dependent on China's domestic market which is instructed by engineering norms. It is a natural choice, especially when the major part of our construction resources come from China." (JN18)

Underlying International GS's reliance on domestic supplies for external markets/bidding was the enterprise's active response to the government's hegemonic order of externalisation (Zou Chu Qu policy). Overseas SOEs were encouraged to stimulate Chinese industries by creating export and cooperation opportunities. Rather than adhering to the policy in a reluctant way due to the coercive nature of the instruction, this hegemonic demand featured 'enthusiastically' in International GS and included the establishment of three domestic sub-companies which handled the material, labour and engineering equipment supplies to the overseas market. As the director of GSMT stated:

"For a long time we traded with suppliers on behalf of local government as we were (GSMT) a part of the procurement department of Construction GS before the establishment of International GS. There are greater political implications in the new era of Zou Chu Qu as we now work to bridge domestic material suppliers with our overseas projects in a hope that both sides would benefit from the political dividend (the policy of Zou Chu Qu ${ }^{16}$ encouraged in $12^{\text {th }}$ Plan)." (LZ9)

Many previous studies conceptualised China's political context as a 'constraint' on the operation of accounting and control practices (Xu \& Uddin, 2008; Li \& Tang, 2009; Zan \& Xue, 2011; O'Connor et al., 2011; Yang \& Modell, 2015). In a similar vein, the mixed use of a 'modern' project budget and 'traditional' engineering norms by International GS managers seemed contradictory and unhelpful. Such a co-existence is possible, however, if not necessary, in that it served the common purpose of assisting China's hegemony plan for expansion. While the adoption of the project budget could be seen

\footnotetext{
16 The phrase "Zou Chu Qu" can be directly translated as 'going outside', which was proposed as a significant strategy within China's economic reform policy by promoting the global impact of China's industries and enterprises via international trade and cooperation, export and imports and overseas investment and operations.
} 
to improve the acceptance and appreciation of Chinese SOEs in the international economy, the use of engineering norms at the same time revealed the SOE manager's tactics for fulfilling their political roles by providing a convenient route for China's domestic exports. This reflected an important economic strategy in light of the CCP's hegemonic process of internationalisation.

In terms of its influence on the economic perspective, the implementation of accounting and control practices has also been articulated with the ideational part of the hegemonic transition. For instance, although GSLZ specified three areas in which to achieve targeted costs, in practice we found that most managerial attention has been on controlling on-site costs. Under the slogan "making projects move", the principle of GSJN's construction work can be described as a holistic material and labour turnover system with a unified schedule of equipment usage allowing for inter-project coordination to mitigate duplication of the same costs across different construction sites. Mutual communication and coordination among project teams became crucial to prepare an overall plan for each project's resource allocation. According to the plan, sufficient materials were delivered to different construction sites at the beginning of a planned period to minimise the shipping fees. Workers and equipment were then constantly transported from one site to another, thereby seeking to reduce the losses associated with work stoppages and mechanical wastage. The implementation of onsite control practices greatly relied on precision, discipline and compliance with the overall scheduling, reflective of the military management traditions inherited from Cheng Jian Zhi. One project manager commented that the "construction site is as same as battlefield, where obedience to command is the key" (LZ17).

While this apparent 'regression' to old managerial modes was advocated to ensure on time project delivery and cost control, managers' favourable attitudes towards this control practice was not merely borne out of its technical benefits. A manager commented:

"I think you have heard this too many times, but I still need to say, military management is our spirit - comply with commands and contribute to the collective good. It is a spirit inherited from the most difficult period of the company and the country; it represents our discipline, diligence and unity. Hence we need this to motivate morale in real work, which is particularly important at the current time as local employees and our young managers may not understand the essence underlying this approach." (JN15)

Arguably, this comment suggests that what lies behind the persistence of Cheng Jian Zhi is the continuation of core ideas and values from the socialist development of China, namely the primacy of national interests, the pursuing of unity and collaboration, and collective efforts for the common good. In the new era of China's hegemonic internationalisation, all of these goals were presented as determining factors in providing an alternative form of Chinese leadership and influence at the global level. In other words, rather than the ideational shackle that many previous studies portrayed (Li \& Tang, 2009; Yang \& Modell, 2015), what became embodied in the implementation of traditional approaches such as militarised management was the SOE managers' spontaneous response to the state's hegemonic externalisation, and the articulation of the state's ideological essence in SOE overseas practices. This has 
been expressed in managers' emotional attachment to these historic methods and the underlying SOE spirit. As one GSJN manager stated:

"Although the company has learned and developed to have a similar structure and management as western companies, we still don't want to lose our SOE identity. It is not only for gaining acceptance by the state, favourable policies and more opportunities for inter-government cooperation. It is the principle and unique merits of being a Chinese enterprise and how we distinguish ourselves from western companies. It is particularly important when working abroad, we need to remember that we are not only representing ourselves, but also the image of the country behind us." (JN16)

In contrast to many previous studies which recognised preference/insistence of Chinese SOEs for historical accounting and control practices as barriers to, or a sign of resistance to, modernisation, we suggest that the coexistence of modern and traditional practices in SOEs arises from the purposeful design of the CCP's deployment of the hegemonic order by showcasing the government's determination to incorporate and contribute to the global economy, whilst retaining its political and ideological objectives to become an alternative global superpower. In other words, the functionality of accounting and control practices was not the primary concern of the SOE and its managers. Building on the words of Cox (1981, p. 135), managers may move with the pressures or resist and oppose them, but they cannot ignore them, and "...to the extent that they do successfully resist a prevailing historical structure, they buttress their actions with an alternative, emerging configuration of forces, a rival structure" (1981, p. 135). What therefore predominates in the use of accounting and control practices is the underlying political interests, which we conceptualise as part of the key activities and programmes within the company: ideological and political work.

\section{Ideological and political work}

During the in-depth interviews, it was noted that managers, particularly those in GSJN, admitted that the enterprise's 'bottom-line' economic performance has been sometimes compromised by the political outlook on the implementation of accounting and control practices. The deputy general manager of GSJN commented:

"Ghana is nothing like China, policies, economy, currency and market, in here all of these can change very quickly. A very profitable project at the beginning would end up with nothing, and that's something unmanageable with our current approaches, which paid less attention to the market. Besides, our militarised management is not so welcomed by local people which sometimes led to delays in construction work." (JN3)

Inevitably, such a compromise could not convince everyone in GSJN and some managers expressed their concerns about the financial viability of the enterprise's overseas operations. One project manager stated:

"... Our company is very politically oriented as we spent more time and energy on politics than business. We could have had better management but there is always something beyond business in real work. For example, we have to carry out some unprofitable projects simply because it is an assigned political task as a part of intergovernmental cooperation. (JN17) 
When faced with the commercial realities and the financial logics flowing from the accounting and control practices, International GS managers reverted to a form of 'communal' controls (Alawattage \& Wickramasinghe, 2008) to help mitigate the contradictions involved in managerial activities and decision-making. These communal controls are typically known as "Si Xiang Zheng Zhi Gong Zuo" in Chinese, or ideological and political work. The concept of ideological and political work was initiated in the 1950 s by Mao, the then party leader, and was then constantly promoted by the CCP to become a concrete and indispensable social and educational activity in Chinese organisations and the education system. Drawn from communist classics, this work sought to instil certain political ideas, views and standpoints as the guidance and baseline for people's social behaviours. The content of such work is regularly updated to reflect the CCP's latest political directions, which are conveyed to individuals by an organisation's party branches via mandatory (mainly in state-owned enterprises and universities) learning activities.

In International GS, ideological and political work has been effectively tailored and adopted by managers seeking to 'harmonise' their conception of hegemonic progress when political and economic interests 'collide'. Initiated by the CCP's branch of International GS, the essence of such work, as reflected in its managerial manual, is:

"a work to ensure that the political and ideological thoughts of overseas teams are consistent with the Party and the state's current political directions and economic deployment. The work must be conducted on the basis of Marxism-Leninism, Maoism, Dengism... and exercised to improve communication, solidarity and business management."

This 'work' has been consistently recognised as the lifeblood of SOE activity and strategy, through which specific practices and methods were designed, and including the adoption of accounting and control practices. In effect, such work materialises the political nature of multinational SOEs and seeks to embed government policy and political thoughts as part of the learning and reflection process of Chinese managers and employees. The HR director commented:

"...most importantly we must ensure that everyone in this company understands three questions: why we are here? what make us unique from others? and what do we stand for?... and the answers can be expressed in three sentences - 1. our identity as CCP member, Chinese citizen and SOE employee is unchangeable, 2. our responsibility to create revenue, to dedicate ourselves to our job roles and to win honour for our country is unchangeable, and 3. our ideals and conviction to socialism is unchangeable".

For GSJN, this broad target has been broken down into specific aspects to match local conditions. Routine seminars and learning sessions are organised to discuss and share thoughts regarding new political guidance. Chinese expatriates are organised into groups to receive patriotic education via reading articles or watching videos. Retrospective learning and exhibition events about history of Construction GS and the experiences of its working model are advocated, within which the old generation's discipline, compliance to the collective, diligence and hard work are particularly admired traits. Furthermore, the SOE's path of development, including the adoption of modern accounting and control practices and 'success,' are portrayed as an inspirational story, which has resonated with the state's reforms and the CCP's leading 
role in the country's development. Chinese expatriates working in Africa, especially those newly recruited or at a younger age, are thus expected to appreciate the nationalist 'spirit' of this enterprise and their work abroad as an honoured 'mission'. As one manager stated:

"...When we first came here (Ghana) in 70s, we had nothing but local suspicions and hostility, it is not just because we are strangers but also because China was poor back then. Some thirty years passed and we are now one of the biggest construction companies in Ghana and we couldn't have achieved it without the support of our country which is getting stronger and more powerful because of the CCP's lead...For the ideological work, we must let our young people know the history, the close bond between us and our country, and make them proud of what they are doing here. We are not just working for our own benefit but also as a part of our country's prosperity and renaissance, as only a strong China can lead us to a bright future." (JN4)

This nationalist connotation facilitated Chinese employees to embrace a unified understanding of their 'identity' in a foreign country, within which their own work and contributions are elevated as contributions to the state, and their loyalty to the CCP is highlighted and interpreted as a patriotic act. In this sense, the ideological and political work served the purpose of creating consent for the CCP's hegemonic direction at the enterprise level, through which the ideological discourses such as "peaceful rise" and "Chinese Dream" find their concrete realisation in the overseas operation of SOEs.

Ideological and political work has also been entrenched within people's daily life and personal welfare. Many 'showcase windows', providing government and Party information, were set up in workplaces and halls of residence. For project teams far away from the headquarters, a CCP sub-branch synchronises practices with the headquarters level. More importantly, top managers are requested to "link politicalideological work with the resolution of employee's practical problems", for which improving the employee's material and cultural life, solving the employee's emotional and morale problems, and supporting and comforting the employee's family in China, are also recognised as important parts of the ideological and political work. As the general manager explained:

"Ideological and political work would unite thoughts and create a cohesive, disciplined, and efficient team with high morale. However, successful work must be realistic and starts from what employee cares about... You can't expect employees to accept your opinions and follow your lead if they even don't like you and accept you. So how do you make yourself welcomed? It's very simple, getting to know each employee's difficulties in daily life, trying to solve their problems and taking care of them. It is especially important for those of us who live and work far away from our hometowns without any help from the outside." (JN2)

The general manager's comments reflect a specific approach to contextualising abstract political work in the workplace by emphasising the mutual communication between employees and managers. While employee wellbeing difficulties can be communicated, appreciated and solved as part of the enterprise's political tasks, it is more likely to encourage a favourable attitude towards the political work and the Party branch behind the work, which in turn promotes consent to the established hegemony. Overall, this specialised control has been tailored to fit the International GS's overseas 
working conditions, which enabled the making of collective identities among the company's Chinese expatriates and therefore facilitated the form of a historic bloc that is consistent with the state's hegemonic appeals (Gramsci, 1971; Cox, 1981; Bieler \& Morton, 2004).

The use of ideological and political work demonstrated the unique capability of SOE managers, with their political acumen and business expertise, in articulating and maintaining the CCP's hegemonic arrangement at the enterprise level. Chinese employees were united, and agreed upon specified political goals, whilst queries about accounting and control functions were diverted in favour of political imperatives. In other words, while the adoption of modern accounting and control practices has been appreciated as a necessity for acquiring global recognition for China's hegemonic externalisation, an insistence on traditional methods was also advocated as the essence of China's alternative hegemonic progress. The latter comes as a result of ideological and political work which unified the thoughts of Chinese expatriates under somewhat contradictory (from an observer's perspective) working conditions. Furthermore, our findings showed that as a return for fulfilling government's hegemonic demand, the 'self-sacrifice' that the enterprise might have made at the economic level could anyway be compensated. For instance, managers in GSJN indicated that they were offered greater support and convenience for participating in inter-government cooperation, which resulted in a favourable economic outcome to offset the loss generated by their managerial activities. One senior manager explained:

"...Governmental cooperative projects normally do not go through an open bidding process, as we are invited to participate in the project and the construction quantities and price are negotiated between us and the government. It is a much flexible approach and we can strive for more favourable conditions, not to mention that we could avoid intensive competition in the open bidding process..." (JN3)

The implementation of ideological and political work, combined with the selective adoption of accounting and control practices, thus reflected the significance of the multinational SOE as a state apparatus in the latest stage of China's hegemonic externalisation. While SOE managers purposefully design and equip their overseas operations as the frontline of China's state international expansion, a reciprocal relationship between the government and the SOE is established which supports the latter in continuing its overseas expansion as a response to the former's hegemonic arrangement.

\section{Conclusion}

This paper set out to explore how accounting and control practices operate in the multinational operations of China's state-owned enterprises in the context of the state's politically driven economic reform. In line with the theory of hegemony (Gramsci, 1971; Joseph, 2002), we sought to explain how the CCP, as the monopolistic dominant player of the state, created and maintained its political hegemony via the discourse of the pursuit of "economic development" and corresponding adjustments in accounting and control practices, which are morally and intellectually supported by ideological and political work done at the national to the organisational levels. Drawing on Neo-Gramcian conceptions, such as Laclau and Mouffe's hegemonic articulation 
and Cox's hegemonic internationalisation, our historical investigation incorporates the SOE's accounting development towards the state's economic and internationalising progressions, thereby cascading the hegemonic analysis from the superstructural level (Goddard, 2002; Ezzamel et al., 2007; Yee, 2009) to the economic and enterprise levels. This further enabled us to identify the multinational SOE as the important apparatus in China's latest hegemonic externalisation, in which SOE managers as 'state agents', greatly facilitated the CCP's hegemonic building of practices by accommodating accounting and control practices in line with political and ideological demands.

Consequently, our paper makes two key research contributions. Firstly, hegemonic accounting studies explain the accounting system as a social and political means with which to obtain the consent that is necessary for the dominant group to maintain its supremacy (Cooper, 1995; Goddard, 2002; Alawattage \& Wickramasinghe, 2008). In this sense, hegemony is a purposefully designed 'strategy' (Ashraf \& Uddin, 2015) through which the dominant group's ideas can be easily conveyed to the dominated groups. While this top-down approach is important to understanding the political nature of accounting, it seems that a hegemonic analysis has remained bound within the superstructures of a state: the power relations between the political and civil societies and the latter's ability to develop and diffuse consented ideas and values, for example, in terms of accounting regulations. Our case study, by investigating the hegemonic building and maintenance within a multinational enterprise, brings to light the less mentioned 'economic base' of a state and its role in hegemonic development. It is clearly evident that rather than a passive receiver of the state's hegemonic instructions, the case enterprise actively accommodated and coordinated with the state in the hegemonic process, in which accounting and control practices are developed and used purposefully to articulate the state's political demands with the enterprise's management and operations.

Secondly, this paper also contributes to the ideological perspective of hegemonic accounting analysis. While Gramsci's idea of 'materialised ideology' has been interpreted as the formation of accounting discourse, regulation and professionalisation as the embodiment of ideology (Goddard, 2002, 2005; Ezzamel et al., 2007; Yee, 2009), this paper, by mobilising Laclau and Mouffe's key concepts of 'articulation', 'empty signifier' and 'nodal points', developed an analytical framework to explain how manufactured ideological objects (e.g. economic development, accounting and control practices) evolve, are perceived and exercised in economic practice, and its underlying hegemonic arrangement over time. This new research angle further responds to the recent call to explore the reflections from an agential aspect, such as industrial practitioners, or ideological hegemony (Ashraf \& Uddin, 2015, Mantzari \& Georgiou, 2018). Our case study in China offers a contribution to the agential analysis of hegemony by explaining how top SOE managers articulate political ideologies and hegemonic demand alongside the enterprise's economic activities in the overseas markets. We contend that a focus on the wider role of accounting and control practices in the context of multinational operations, mediated by ideology and political work, serves to bring insights beyond the mainstream dialectic of Western vs. non-Western practices.

The concept of hegemony has been increasingly appreciated and adopted in Chinarelated studies because of its critical angle in explaining China's unique political and 
economic mechanisms and accounting practices under this specific regime of control (Yee, 2009; Xu et al., 2014, 2017). However, previous studies tend to overemphasise the history of the state's building of ideological hegemony and its embeddedness in the accounting realm, for which researchers heavily relied on second-hand data and cross-sectional primary data such as official archives and government documents. Although a historical investigation is also important for our analysis, our in-depth case study of a large multinational SOE provides empirical evidence offering new insight into China's politically driven economic reform and policies, and particularly its current path of seeking global influence and increased overseas expansion (Grimm, 2014; Wang \& Elliot, 2014; Huang, 2011). While many recent studies do investigate the significant influence of Chinese government, and the concurrent politically driven ODFI, state owned enterprise (SOE) transformation and corporate governance on the establishment and development of Chinese MNCs (Lu, Tao \& Yang, 2010; Cho \& Huang, 2011; Klossek, Linke \& Nippa, 2012; Huang, 2011; Quer et al., 2012; Cui \& Jiang, 2012), our hegemonic analytical framework could help future research to shed light on the understanding of China's political and economic initiatives and dynamism in global markets, as well as the design and use of accounting and control practices in the context of a strategy of multinational investment. 


\section{Appendix A}

\begin{tabular}{|c|c|c|c|c|c|c|c|}
\hline \multicolumn{8}{|c|}{ GSLZ } \\
\hline $\begin{array}{l}\text { Interviewee } \\
\text { Code }\end{array}$ & Job Position & Department & Nationality & Place & Date & $\begin{array}{c}\begin{array}{c}\text { Duration } \\
\text { (min) }\end{array} \\
\end{array}$ & Remark \\
\hline LZ1 & $\begin{array}{l}\text { General } \\
\text { Manager }\end{array}$ & $\begin{array}{l}\text { GSLZ(Head } \\
\text { Office) }\end{array}$ & China & China & $24 / 08 / 2012$ & $90 / 30$ & $\begin{array}{c}\text { Re- } \\
\text { interviewed, } \\
16 / 11 / 2012\end{array}$ \\
\hline LZ2 & $\begin{array}{c}\text { Deputy } \\
\text { Manager }\end{array}$ & $\begin{array}{l}\text { GSLZ(Head } \\
\text { Office) }\end{array}$ & China & China & 27/08/2012 & 60 & \\
\hline LZ3 & $\begin{array}{c}\text { Deputy } \\
\text { Manager }\end{array}$ & $\begin{array}{l}\text { GSLZ(Head } \\
\text { Office) }\end{array}$ & China & China & 27/08/2012 & 60 & \\
\hline LZ4 & Chief Engineer & $\begin{array}{c}\text { GSLZ(Head } \\
\text { Office) }\end{array}$ & China & China & $28 / 08 / 2012$ & 90 & \\
\hline LZ5 & CFO & $\begin{array}{l}\text { GSLZ(Head } \\
\text { Office) }\end{array}$ & China & China & 29/08/2012 & 120 & $\begin{array}{c}\text { Re- } \\
\text { interviewed, } \\
\text { 24/10/2013 }\end{array}$ \\
\hline LZ6 & Director & $\begin{array}{l}\text { Human } \\
\text { Resource }\end{array}$ & China & China & 30/08/2012 & $120 / 30$ & $\begin{array}{c}\text { Re- } \\
\text { interviewed,0 } \\
6 / 02 / 2014 \\
\end{array}$ \\
\hline LZ7 & Director & Engineering & China & China & $31 / 08 / 2012$ & 60 & \\
\hline LZ8 & Director & Operation & China & China & 03/09/2012 & $60 / 20$ & $\begin{array}{c}\text { Re- } \\
\text { interviewed, } \\
13 / 06 / 2013\end{array}$ \\
\hline LZ9 & Director & GSMT & China & China & 03/09/2012 & 90 & \\
\hline LZ10 & Director & GSLS & China & China & 04/09/2012 & 60 & \\
\hline LZ11 & Director & GSEE & China & China & 04/09/2012 & 90 & \\
\hline LZ12 & Accountant & $\begin{array}{c}\text { Financial \& } \\
\text { Auditing }\end{array}$ & China & China & $05 / 09 / 2012$ & 60 & \\
\hline LZ13 & Accountant & $\begin{array}{c}\text { Financial \& } \\
\text { Auditing }\end{array}$ & China & China & $06 / 09 / 2012$ & 45 & \\
\hline LZ14 & Accountant & $\begin{array}{c}\text { Financial \& } \\
\text { Auditing }\end{array}$ & China & China & 06/09/2012 & 60 & \\
\hline LZ15 & $\begin{array}{l}\text { Projector } \\
\text { Manager }\end{array}$ & $\begin{array}{c}\text { Safety \& } \\
\text { Production }\end{array}$ & China & China & 07/09/2012 & 45 & \\
\hline LZ16 & $\begin{array}{l}\text { Projector } \\
\text { Manager }\end{array}$ & $\begin{array}{c}\text { Technique \& } \\
\text { Quality }\end{array}$ & China & China & 07/09/2012 & 30 & \\
\hline LZ17 & $\begin{array}{l}\text { Projector } \\
\text { Manager }\end{array}$ & Engineering & China & China & $10 / 09 / 2012$ & 40 & \\
\hline LZ18 & $\begin{array}{c}\text { Operational } \\
\text { Manager }\end{array}$ & Operation & China & China & $10 / 09 / 2012$ & 30 & \\
\hline LZ19 & $\begin{array}{c}\text { Operational } \\
\text { Manager }\end{array}$ & Operation & China & China & 05/09/2012 & 60 & \\
\hline LZ20 & $\begin{array}{c}\text { Middle } \\
\text { Manager }\end{array}$ & $\begin{array}{l}\text { Human } \\
\text { Resource }\end{array}$ & China & China & $31 / 08 / 2012$ & 30 & \\
\hline
\end{tabular}




\begin{tabular}{|c|c|c|c|c|c|c|c|}
\hline \multicolumn{8}{|c|}{ GSJN } \\
\hline $\begin{array}{l}\text { Interviewee } \\
\text { Code }\end{array}$ & Job Position & Department & Nationality & Place & Date & $\begin{array}{c}\text { Duration } \\
\text { (min) }\end{array}$ & Remark \\
\hline JN1 & Chairman & $\begin{array}{l}\text { GSJN(Head } \\
\text { Office) }\end{array}$ & China & Ghana & $11 / 07 / 2013$ & 120 & \\
\hline JN2 & $\begin{array}{l}\text { General } \\
\text { Manager }\end{array}$ & $\begin{array}{l}\text { GSJN(Head } \\
\text { Office) }\end{array}$ & China & Ghana & $04 / 07 / 2013$ & $90 / 30$ & $\begin{array}{c}\text { Re- } \\
\text { interviewed, } \\
18 / 12 / 2013\end{array}$ \\
\hline JN3 & $\begin{array}{l}\text { Deputy } \\
\text { Manager }\end{array}$ & $\begin{array}{l}\text { GSJN(Head } \\
\text { Office) }\end{array}$ & China & Ghana & $04 / 07 / 2013$ & 90 & \\
\hline JN4 & Chief Engineer & $\begin{array}{l}\text { GSJN(Head } \\
\text { Office) }\end{array}$ & China & Ghana & $03 / 07 / 2013$ & 120 & \\
\hline JN5 & CFO & $\begin{array}{l}\text { GSJN(Head } \\
\text { Office) }\end{array}$ & China & Ghana & $10 / 07 / 2013$ & $120 / 30$ & $\begin{array}{c}\mathrm{Re}- \\
\text { interviewed, } \\
10 / 04 / 2014\end{array}$ \\
\hline JN6 & $\begin{array}{c}\text { Deputy } \\
\text { Manager }\end{array}$ & $\begin{array}{c}\text { GSJN(Head } \\
\text { Office) }\end{array}$ & China & Ghana & $10 / 07 / 2013$ & 60 & \\
\hline JN7 & Director & $\mathrm{CSC}$ & China & Ghana & $09 / 07 / 2013$ & 90 & \\
\hline JN8 & Director & GSID & China & Ghana & 09/07/2013 & $60 / 20$ & $\begin{array}{c}\text { Re- } \\
\text { interviewed, } \\
05 / 03 / 2014 \\
\end{array}$ \\
\hline JN9 & Director & GSM & China & Ghana & $08 / 07 / 2013$ & 60 & \\
\hline JN10 & Director & SP & China & Ghana & 09/07/2013 & 120 & \\
\hline JN11 & Director & GSIHM & China & Ghana & $10 / 07 / 2013$ & 60 & \\
\hline $\mathrm{JN} 12$ & Director & GSIT & China & Ghana & $11 / 07 / 2013$ & 60 & \\
\hline JN13 & Director & $\begin{array}{l}\text { Human } \\
\text { Resources }\end{array}$ & China & Ghana & $12 / 07 / 2013$ & $120 / 30$ & $\begin{array}{c}\text { Re- } \\
\text { interviewed, } \\
21 / 11 / 2013 \\
\end{array}$ \\
\hline JN14 & Director & Engineering & China & Ghana & $11 / 07 / 2013$ & 60 & \\
\hline JN15 & Director & Project & China & Ghana & 08/07/2013 & 90 & \\
\hline JN16 & Director & Operation & China & Ghana & $08 / 07 / 2013$ & 60 & \\
\hline JN17 & Project Manager & Project & China & Ghana & $03 / 07 / 2013$ & 45 & \\
\hline JN18 & Project Manager & $\mathrm{CSC}$ & China & Ghana & $01 / 07 / 2013$ & 40 & \\
\hline JN19 & $\begin{array}{c}\text { Secretary } \\
\text { General }\end{array}$ & Administration & China & Ghana & $02 / 07 / 2013$ & 90 & \\
\hline $\mathrm{JN} 20$ & Middle Manager & GSIHM - HR & Ghana & Ghana & $05 / 07 / 2013$ & 60 & \\
\hline JN21 & Middle Manager & $\begin{array}{c}\text { GSIHM - } \\
\text { Marketing }\end{array}$ & Ghana & Ghana & $05 / 07 / 2013$ & 60 & \\
\hline $\mathrm{JN} 22$ & Middle Manager & Accounting & Ghana & Ghana & $12 / 07 / 2013$ & 60 & \\
\hline JN23 & Middle Manager & Accounting & Ghana & Ghana & $12 / 07 / 2013$ & 60 & \\
\hline JN24 & Middle Manager & SP - Production & Ghana & Ghana & $03 / 07 / 2013$ & 45 & \\
\hline JN25 & $\begin{array}{c}\text { Project } \\
\text { Appraiser }\end{array}$ & Operation & Ghana & Ghana & $04 / 07 / 2013$ & 45 & \\
\hline JN26 & Accountant & Accounting & China & Ghana & $01 / 07 / 2013$ & 60 & \\
\hline $\mathrm{JN} 27$ & Project Manager & $\mathrm{CSC}$ & China & Ghana & $02 / 07 / 2013$ & 60 & \\
\hline
\end{tabular}




\section{Appendix B}

\section{Extracted examples of engineering norms}

\begin{tabular}{|c|c|c|c|c|c|c|}
\hline \multicolumn{7}{|c|}{ Engineering Norm of Air Brick Wall $(190 * 290 * 190$, M2.5) } \\
\hline Quota Code & \multicolumn{6}{|c|}{$3-11-1$} \\
\hline Quota Item & \multicolumn{6}{|c|}{ 190mm Air Brick Wall, 190*290*190, Cement Mortar M2.5 } \\
\hline Unit & \multicolumn{6}{|c|}{ m3 } \\
\hline Cost Types & Cost Code & Cost Description & Quantity & $\begin{array}{l}\text { Unit } \\
\text { Price }\end{array}$ & Cost & Unit \\
\hline Labour & R8000 & General Work Day & 1.53 & 23.43 & 35.85 & $\begin{array}{l}\text { Work } \\
\text { Day }\end{array}$ \\
\hline \multirow{3}{*}{ Material } & 2TH7 & $\begin{array}{c}\text { Cement Mortar M2.5, } \\
\text { Level } 32.5 \\
\end{array}$ & 0.08 & 111.54 & 8.92 & m3 \\
\hline & 35 & Water & 0.11 & 0.84 & 0.09 & m3 \\
\hline & TB0173 & Air Brick 190*290*190 & 0.08 & 1364 & 122.76 & 1000 \\
\hline Equipment & $\mathrm{J} 3075$ & Mortar Mixer 200L & 0.01 & 50.03 & 0.5 & $\begin{array}{c}\text { Machine } \\
\text {-team }\end{array}$ \\
\hline
\end{tabular}

\begin{tabular}{|c|c|c|c|c|}
\hline \multicolumn{5}{|c|}{ Engineering Norm of Prefabricated Reinforced Concrete Pile Extension (2-33, 2-34) } \\
\hline \multicolumn{3}{|c|}{ Quota Code } & $2-33$ & $2-34$ \\
\hline \multicolumn{3}{|c|}{ Quota Item } & \multicolumn{2}{|c|}{$\begin{array}{c}\text { Prefabricated Reinforced Concrete } \\
\text { Pile Extension }\end{array}$} \\
\hline Cost Types & Cost Description & Cost Unit & Angled Steel & Plated Steel \\
\hline Labour & General Work Day & Work Day & 18.35 & 19.16 \\
\hline \multirow{4}{*}{ Material } & Angled Steel & $\mathrm{kg}$ & 80 & - \\
\hline & Welding Rod & $\mathrm{kg}$ & 6.5 & 53.2 \\
\hline & Plated Steel & $\mathrm{kg}$ & - & 599 \\
\hline & Shim Plate & $\mathrm{kg}$ & 1.05 & 1.05 \\
\hline \multirow{3}{*}{ Equipment } & Diesel Pile Driver 4t & Machine-team & 1.53 & 1.37 \\
\hline & $\begin{array}{l}\text { AC Welding machine } \\
\text { 40kva }\end{array}$ & Machine-team & 3.04 & 5.46 \\
\hline & Crawling Crane 15t & Machine-team & 1.53 & 1.37 \\
\hline
\end{tabular}

Derived from Construction Project Consumption Quota, XX Province 


\section{References}

Alawattage, C. \& Wickramasinghe, D. (2008). Appearance of accounting in a political hegemony. Critical Perspectives on Accounting, 19(3), 293-339.

Alawattage, C., Hopper, T., Wickramasinghe, D. (2007). Introduction to management accounting in less developed countries. Journal of Accounting \& Organizational Change, 3(3), 183-191.

Alawattage, C., Wickramasinghe, D. (2009). Institutionalisation of control and accounting for bonded labour in colonial plantations: A historical analysis. Critical Perspectives on Accounting, 20(6), 701-715.

Alawattage, C., Wickramasinghe, D., \& Uddin, S. (2017). Theorising management accounting practices in Less Developed Countries. In Harris, E. (Ed.), The Routledge Companion to Performance Management and Control. England: Routledge.

Ashraf, J. \& Uddin, S. (2015). Military, 'managers' and hegemonies of management accounting controls: A critical realist interpretation. Management Accounting Research, 29, 13-26.

Bates, T.R. (1975). Gramsci and the Theory of Hegemony. Journal of the History of Ideas, 1, 351-366.

Bhimani, A. (1999). Mapping methodological frontiers in cross-national management control research. Accounting, Organizations and Society, 24(5-6), 413-440.

Bieler, A., \& Morton, A. D. (2003). Theoretical and methodological challenges of neoGramscian perspectives in international political economy. International Gramsci Society, 08-28.

Bieler, A., \& Morton, A. D. (2004). A critical theory route to hegemony, world order and historical change: Neo-Gramscian perspectives in International Relations, Capital \& Class, 28(1), 85-113.

Braun, V. \& Clarke, V. (2006). Using thematic analysis in psychology. Qualitative Research in Psychology, 3(2), 77-101. 
Bromwich, M., Wang, G. (1991). Management accounting in China: A current evaluation. The International Journal of Accounting, 26(1), 51-65.

Buzan, B. (2010). China in international society: Is 'peaceful rise' possible? The Chinese Journal of International Politics, 3(1), 5-36.

Campbell, H. (2008). China in Africa: Challenging US global hegemony. Third World Quarterly, 29(1), 89-105.

Carpentier, N., \& Cammaerts, B. (2006). Hegemony, democracy, agonism and journalism: An interview with Chantal Mouffe. Journalism Studies, 7(6), 964-975.

Chalos, P., O'Connor, N., Zijian, X. (1999). A comparative study of budgetary controls in Chinese state and foreign owned enterprises. Advances in Management Accounting, 7, 169-186.

Chalos, P., O'Connor, N.G. (2004). Determinants of the use of various control mechanisms in US-Chinese joint ventures. Accounting, Organizations and Society, 29(7), 591-608.

Chen, A. (2009). Thirty years of Chinese reform---Transition from planned economy to market economy. Asian Social Science, 5(3), 52.

Chen, J.J. (1998). The characteristics and current status of China's construction industry. Construction Management \& Economics, 16(6), 711-719.

Chiwamit, P., Modell, S. \& Yang, C.L. (2014). The societal relevance of management accounting innovations: Economic value added and institutional work in the fields of Chinese and Thai state-owned enterprises. Accounting and Business Research, 44(2), 144-180.

Cho, D.S., Huang, F. (2011) A Study on corporate governance of China's state-owned enterprises - Focus on the role of Baosteel CCP Organization. Journal of International Business Research, 10(1), 137.

Chow, C.W., Duh, R.R., Xiao, J.Z. (2007). Management accounting practices in the People's Republic of China. In Handbook of Management Accounting Research, 2, 941986. 
Chow, C.W., Lindquist, T.M., Wu, A. (2001). National culture and the implementation of high-stretch performance standards: An exploratory study. Behavioral Research in Accounting, 13(1), 85-109.

Chow, G.C. (2011). Economic planning in China. Center for Economic Policy Studies, Princeton: Princeton University.

Cooke, F.L. (2014). Chinese multinational firms in Asia and Africa: Relationships with institutional actors and patterns of HRM practices. Human Resource Management, 53(6), 877-896.

Cooper, C. (1995). Ideology, hegemony and accounting discourse: a case study of the National Union of Journalists. Critical Perspectives on Accounting, 6(3), 175-209.

Corkin, L. (2012). Chinese construction companies in Angola: A local linkages perspective. Resources Policy, 37(4), 475-483.

Cox, R. W. (1981). Social forces, states and world orders: Beyond international relations theory. Millennium, 10(2), 126-155.

Cui, L. \& Jiang, F. (2012). State ownership effect on firms' FDI ownership decisions under institutional pressure: A study of Chinese outward-investing firms. Journal of International Business Studies, 43(3), 264-284.

Dai, N. T., Tan, Z. S., Tang, G., Xiao, J. Z. (2014). IPOs, organisational change, and management accounting change: Evidence from Chinese state-owned and non-stateowned enterprises. Critical Perspectives on Accounting Conference 2014.

Deng, X. (1992). Main points of speeches made in Wuchang, Shengzhen, Zhuhai and Shanghai. Selected works of Deng Xiaoping (Vol. 3, 1994, 2nd ed., pp. 370-383). Beijing: The People's Press.

Douglas, P.C., Wier, B. (2005). Cultural and ethical effects in budgeting systems: A comparison of U.S. and Chinese managers. Journal of Business Ethics, 60(2), 159-174.

Du, F., Tang, G. \& Young, S.M. (2012). Influence activities and favoritism in subjective performance evaluation: Evidence from Chinese state-owned enterprises. The Accounting Review, 87(5), 1555-1588. 
Duh, R.-R., Xiao, J.Z., Chow, C.W. (2009). Chinese firms' use of management accounting and controls: facilitators, impediments, and performance effects. Journal of International Accounting Research, 8(1), 1-30.

Ezzamel, M., \& Xiao, J.Z. (2015). The development of accounting regulations for foreign invested firms in China: The role of Chinese characteristics. Accounting, Organizations and Society, 44, 60-84.

Ezzamel, M., Xiao, J.Z. \& Pan, A. (2007). Political ideology and accounting regulation in China. Accounting, Organizations and Society, 32(7-8), 669-700.

Firth, M. (1996). The diffusion of managerial accounting procedures in the People's Republic of China and the influence of foreign partnered joint ventures. Accounting, Organizations and Society, 21(7-8), 629-654.

Firth, M., Fung, P.M. \& Rui, O.M. (2006). Corporate performance and CEO compensation in China, Journal of Corporate Finance, 12(4), 693-714.

Fleming, D.M., Chow, C.W., Chen, G. (2009). Strategy, performance-measurement systems, and performance: A study of Chinese firms. The International Journal of Accounting, 44(3), 256-278.

Foot, R. (2006). Chinese strategies in a US-hegemonic global order: Accommodating and hedging. International Affairs, 82(1), 77-94.

Gleiss, M. S. (2015). Speaking up for the suffering (br) other: Weibo activism, discursive struggles, and minimal politics in China. Media, Culture \& Society, 37(4), 513-529.

Goddard, A. (2002). Development of the accounting profession and practices in the public sector-a hegemonic analysis. Accounting, Auditing \& Accountability Journal, 15(5), 655-688.

Goddard, A. (2005). Reform as regulation-accounting, governance and accountability in UK local government. Journal of Accounting \& Organizational Change, 1(1), 27-44. 
Gong, X., \& Cortese, C. (2017). A socialist market economy with Chinese characteristics: The accounting annual report of China Mobile. Accounting Forum, 41(3), 206-220.

Gramsci, A. \& Hoare, Q. (1971). Selections from the prison notebooks (Vol. 294). London: Lawrence and Wishart.

Grimm, S. (2014). China-Africa Cooperation: Promises, practice and prospects. Journal of Contemporary China, 23(90), 993-1011.

Hall, S. (1986). The problem of ideology-Marxism without guarantees. Journal of Communication Inquiry, 10(2), 28-44.

Hassard, J., Morris, J., Sheehan, J. \& Yuxin, X. (2010). China's state-owned enterprises: economic reform and organizational restructuring. Journal of Organizational Change Management, 23(5), 500-516.

Hopper, T., Tsamenyi, M., Uddin, S., Wickramasinghe, D. (2009). Management accounting in less developed countries: What is known and needs knowing. Accounting, Auditing \& Accountability Journal, 22(3), 469-514

Howarth, D. (Ed.). (2014). Ernesto Laclau: Post-Marxism, populism and critique. England: Routledge.

Huang, H.C., Lai, M.C., Kao, M.C. \& Chen, Y.C., (2012). Target costing, business model innovation, and firm performance: An empirical analysis of Chinese firms. Canadian Journal of Administrative Sciences/Revue Canadienne des Sciences de I'Administration, 29(4), 322-335.

Huang, X. (2011). Corporate control by Chinese MNCs over their foreign subsidiaries: combining institutional and resource-based perspectives. Labour \& Industry: A Journal of the Social and Economic Relations of Work, 22(1-2), 169-191.

Huang, Y. \& Duncan, R. (1997). How successful were China's state sector reforms? Journal of Comparative Economics, 24(1), 65-78.

Islam, M., Kantor, J. (2005). The development of quality management accounting practices in China. Managerial Auditing Journal, 20(7), 707. 
Joseph, J. (2000). A realist theory of hegemony. Journal for the Theory of Social Behaviour, 30(2), 179-202.

Kernen, A., Lam, K.N. (2014). Workforce localization among Chinese state-owned enterprises (SOEs) in Ghana. Journal of Contemporary China, 23(90), 1053-1072.

Klossek, A., Linke, B.M., Nippa, M. (2012) Chinese enterprises in Germany: Establishment modes and strategies to mitigate the liability of foreignness. Journal of World Business, 47(1), 35-44.

Laclau, E. (1996). Why do empty signifiers matter to politics. Emancipation(s), 36, 46.

Laclau, E., \& Mouffe, C. (2014). Hegemony and socialist strategy: Towards a radical democratic politics. London: Verso Trade.

Li, P., Tang, G. (2009). Performance measurement design within its organisational context-Evidence from China. Management Accounting Research, 20(3), 193-207.

Li, T., \& Belal, A. (2018). Authoritarian state, global expansion and corporate social responsibility reporting: The narrative of a Chinese state-owned enterprise. Accounting Forum, 42(2), 199-217.

Li, W. \& Yang, D.T. (2005). The great leap forward: Anatomy of a central planning disaster. Journal of Political Economy, 113(4), 840-877.

Lieber, A. (2013). The Chinese ideology: Reconciling the politics with the economics of contemporary reform. Journal of Chinese Political Science, 18(4), 335-353.

Lin, Z.J. \& Yu, Z. (2002). Responsibility cost control system in China: A case of management accounting application. Management Accounting Research, 13(4), 447467.

Liu, L.Y.J., Pan, F. (2007). The implementation of activity-based costing in China: An innovation action research approach. British Accounting Review, 39(3), 249-264.

Mantzari, E. \& Georgiou, O. (2018). Ideological hegemony and consent to IFRS: Insights from practitioners in Greece. Critical Perspectives on Accounting, 59, 70-93 
Modell, S., \& Yang, C. (2018). Financialisation as a strategic action field: An historically informed field study of governance reforms in Chinese state-owned enterprises. Critical Perspectives on Accounting, 54, 41-59.

MOFCOM. (2017). Opening remarks by H.E. Xi Jinping president of the People's Republic of China at the leaders roundtable of the belt and road forum for international cooperation. Retrieved from http://www.mofcom.gov.cn/article/i/jyjl///201705/20170502576387.shtml

Nolke, A. (2015). Second image revisited: The domestic sources of China's foreign economic policies. International Politics, 52(6), 657-665

O'Dwyer, B. (2004). Qualitative data analysis: Illuminating a process for transforming a 'messy' but 'attractive' 'nuisance'. In C. Humphrey \& B. Lee (Eds.), The real life guide to accounting research (pp. 391-407). Oxford: Elsevier.

O'Connor, N.G., Chow, C.W., Wu, A. (2004). The adoption of 'western' management accounting/controls in China's state-owned enterprises during economic transition. Accounting, Organizations and Society, 29(3-4), 349-375.

O'Connor, N.G., Deng, J., Luo, Y. (2006). Political constraints, organization design and performance measurement in China's state-owned enterprises. Accounting, Organizations and Society, 31(2), 157-177.

O'Connor, N.G., Vera-Muñoz, S.C., Chan, F. (2011). Competitive forces and the importance of management control systems in emerging-economy firms: The moderating effect of international market orientation. Accounting, Organizations and Society, 36(4-5), 246-266.

Overbeek, H. (2016). Globalizing China: A critical political economy perspective on China's rise. In A.W. Cafruny, L.S. Talani \& G.P. Martin (Eds.), The Palgrave Handbook of Critical International Political Economy (pp. 309-329). London: Palgrave Macmillan.

Peng, B. (2018). China, global governance, and hegemony Neo-Gramscian perspective in the world order. Journal of China and International Relations, 6(1), 48. 
Quer, D., Claver, E. \& Rienda, L. (2012). Political risk, cultural distance, and outward foreign direct investment: Empirical evidence from large Chinese firms. Asia Pacific Journal of Management, 29(4), 1089-1104.

Richardson, A.J. (1989). Corporatism and intraprofessional hegemony: A study of regulation and internal social order. Accounting, Organizations and Society, 14(5-6), 415-431.

Rucki, S.M. (2011). Global economic crisis and China's challenge to global hegemony: a neo-Gramscian approach. New Political Science, 33(3), 335-355.

Sassoon, A.S. (1980). Gramsci's politics (pp. 136-136). London: Croom Helm.

Saull, R. (2012). Rethinking hegemony: Uneven development, historical blocs, and the world economic crisis. International Studies Quarterly, 56(2), 323-338.

Scapens, R.W., Yan, M. (1993). Management accounting research in China. Management Accounting Research, 4(4), 321-341.

Scott, W.R. (2002). The changing world of Chinese enterprise: An institutional perspective. In A.S. Tsui \& C.M. Lau (Eds.), The management of enterprises in the People's Republic of China (pp. 59-78). Boston: Springer.

Sha, K. (2004). Construction business system in China: An institutional transformation perspective. Building Research \& Information, 32(6), 529-537.

Simon, R. (1982). Gramsci's political thought. London: Lawrence \& Wishart.

Smith, A. M. (2012). Laclau and Mouffe: The radical democratic imaginary. England: Routledge.

Spence, C. (2009). Social accounting's emancipatory potential: A Gramscian critique. Critical Perspectives on Accounting, 20(2), 205-227.

Strange, G. (2011). China's post-Listian rise: Beyond radical globalisation theory and the political economy of neoliberal hegemony. New Political Economy, 16(5), 539-559.

Su, X. (2011). Revolution and reform: The role of ideology and hegemony in Chinese politics. Journal of Contemporary China, 20(69), 307-326. 
Thomassen, L. (2016). Hegemony, populism and democracy: Laclau and Mouffe today. Revista Española de Ciencia Política, 40, 161-176.

Trindade d'Ávila Magalhães, D. (2018). The globaliser dragon: How is China changing economic globalisation? Third World Quarterly, 39(9), 1727-1749.

Tsamenyi, M., Sahadev, S., Qiao, Z.S. (2011). The relationship between business strategy, management control systems and performance: Evidence from China. Advances in Accounting, 27(1), 193-203.

Tsui, J.S.L. (2001). The impact of culture on the relationship between budgetary participation, management accounting systems, and managerial performance: An analysis of Chinese and Western managers. The International Journal of Accounting, 36(2), 125-146.

van Helden, J., Uddin, S. (2016). Public sector management accounting in emerging economies: A literature review. Critical Perspectives on Accounting, 41, 34-62.

Wang, F.L. \& Elliot, E.A. (2014). China in Africa: Presence, perceptions and prospects. Journal of Contemporary China, 23(90), 1012-1032.

Wang, Z. (2014). The Chinese dream: Concept and context. Journal of Chinese Political Science, 19(1), 1-13.

Whyte, M.K. (1993). Deng Xiaoping: The social reformer. The China Quarterly, 135, 515-535.

Wojczewski, T. (2018). Global power shifts and world order: The contestation of 'western' discursive hegemony. Cambridge Review of International Affairs, 31(1), 3352.

Wu, J., \& Boateng, A. (2010). Factors influencing changes in Chinese management accounting practices. Journal of Change Management, 10(3), 315-329.

Wu, J., Boateng, A., Drury, C. (2007). An analysis of the adoption, perceived benefits, and expected future emphasis of western management accounting practices in Chinese SOEs and JVs. International Journal of Accounting, 42(2), 171-185. 
Xiao, J.Z., Weetman, P. \& Sun, M. (2004). Political influence and coexistence of a uniform accounting system and accounting standards: Recent developments in China. Abacus, 40(2), 193-218.

Xing, L. \& Shaw, T.M. (2013). The political economy of Chinese state capitalism. Journal of China and International Relations, 1(1), 88-113.

$\mathrm{Xu}, \mathrm{C}$ (2011). The fundamental institutions of China's reforms and development. Journal of Economic Literature, 49(4), 1076-1151.

Xu, L., Cortese, C. \& Zhang, E. (2013). Exploring hegemonic change in China: A case of accounting evolution. Asian Review of Accounting, 21(2), 113-127.

Xu, L., Cortese, C. \& Zhang, E. (2014). Ideology diffusion and the role of accounting: A Gramscian approach to understanding China's transition from 1949 to 1957. Accounting History, 19(4), 434-451.

Xu, L., Cortese, C. \& Zhang, E. (2017). The interplay between accounting professionals and political ideologies: The emergence of Chinese accounting standards from 1978 to 1992. Accounting History, 23(3), 360.378.

Xu, W., Uddin, S. (2008). Public sector reforms, privatisation and regimes of control in a Chinese enterprise. Accounting Forum, 32(2), 162-177.

Yan, A., Gray, B. (1994). Bargaining power, management control, and performance in United States-China joint ventures: A comparative case study. Academy of Management Journal, 37(6), 1478-1517.

Yang, C., Modell, S. (2013). Power and performance: Institutional embeddedness and performance management in a Chinese local government organization. Accounting, Auditing \& Accountability Journal, 26(1), 101-132.

Yang, C., Modell, S. (2015). Shareholder orientation and the framing of management control practices: A field study in a Chinese state-owned enterprise. Accounting, Organizations and Society, 45, 1-23. 
Yee, H. (2009). The re-emergence of the public accounting profession in China: A hegemonic analysis. Critical Perspectives on Accounting, 20(1), 71-92.

Yee, H. (2012). Analyzing the state-accounting profession dynamic: Some insights from the professionalization experience in China. Accounting, Organizations and Society, 37(6), 426-444.

Zan, L., Xue, Q. (2011). Budgeting China. Macro-policies and micro-practices in public sector changes. Accounting, Auditing \& Accountability Journal, 24(1), 38-62.

Zhang, D. (2018). The concept of 'community of common destiny' in China's diplomacy: Meaning, motives and implications. Asia \& the Pacific Policy Studies, 5(2), 196-207.

Zhang, E., \& Andrew, J. (2016). Rethinking China: Discourse, convergence and fair value accounting. Critical Perspectives on Accounting, 36, 1-21.

Zhang, X. (2017). Chinese capitalism and the maritime silk road: A world-systems perspective. Geopolitics, 22(2), 310-331. 